\title{
ARENITOS EÓLICOS DA FORMAÇÃO AREADO (BACIA CRETÁCEA DO SÃO FRANCISCO): CARẢCTERIZAÇÃO, DIAGÊNESE E ASPECTOS QUÍMICOS
}

\author{
GERALDO N.C. SGARBI*
}

\begin{abstract}
EOUAN SANDSTONES OF THE CRETACEOUS AREADO FORMATION (SAO FRANCISCO BASIN): GENERAL DESCRIPTION, DIAGENESIS AND CHEMICAL ASPECTS. Some sandstones of the Três Barras Member (Areado Formation, São Francisco Basin) show clear evidence of subaerial deposition observed both in outcrops and in microscopic and submicrpscopic scales. Locally these sandstones were subjected to intense diagenetic process changing original mineralogical and textural properties of the sediments. They have been cemented by authigenic potassium feldspar, which occurs as overgrowth on detrital grains reaching five to ten micrometers in diameter, and by authigenic intergranular silica and calcite, which are forming respectively typical silcretes and calcretes.
\end{abstract}

Keywords: Red beds, Cretaceous, eolian sedimentation, sedimentary petrography, sedimentary petrology, diagenesis of sandstones, chemical composition of sandstones.

\begin{abstract}
RESUMO Alguns arenitos do Membro Três Barras da Formação Areado, Bacia do São Francisco, mostram claras evidências de deposição eólica, observadas tanto em afloramentos como em escalas microscópica e submicroscópica. Localmente, foram submetidos a processos diagenéticos que originaram padrões de porosidade, textura e mineralogia bastante diferentes daqueles observados na rocha original. Os arenitos foram cimentados por feldspato potássico sobrecrescido em grãos detríticos, bem como por silica e calcita, de natureza intergranular, formando respectivamente silcretes e calcretes típicos.
\end{abstract}

Palavras-chaves: Camadas vermelhas, Cretáceo, sedimentação eólica, petrografia sedimentar, petrologia sedimentar, diagênese de arenitos, composição química de arenitos.

INTRODUÇÃO Este estudo constitui uma síntese de parte dos trabalhos de uma dissertação de mestrado sobre a Formação Areado, Bacia do São Francisco, desenvolvida no Departamento de Geologia da Universidade Federal do Rio de Janeiro (Sgarbi 1989).

A área investigada localiza-se no oeste do Estado de Minas Gerais, na região do Alto Rio Paranaíba, tendo sido objeto de mapeamento geológico em escala 1:25.000 e abrangendo cerca de $450 \mathrm{~km}^{2}$ da borda oriental do Planalto da Mata da Corda (Fig. 1).

TRABALHOS PRÉVIOS Os estudos anteriores sobre a Formação Areado (Bacia do São Francisco) que refletem condições paleoclimáticas áridas e semi-áridas do Cretáceo Inferior, iniciaram-se com Arrojado Lisboa (1906), o qual descreveu pela primeira vez seixos facetados nas cabeceiras dos Rios Abaeté e Borrachudos, não estabelecendo, contudo, idéias precisas sobre sua origem. Posteriormente, Freyberg (1932), ao estabelecer formalmente a seqüência estratigráfica local, situou os seixos polidos no Conglomerado Abaeté, membro basal da Formação Areado, embora não tenha considerado a gênese desses clastos.

Guimarães (1951) comentou a grande extensão horizontal do Conglomerado Abaeté, da ordem de milhares de quilômetros quadrados, em contraposição a sua reduzida espessura, da ordem de poucos metros. Aquele autor sugeriu, para os seixos facetados, origem glacial associada a tilitos carboníferos que teriam atingido p alto vale do Rio São Francisco. Hasui (1968) apresentou o primeiro mapa geológico da região do Triângulo Mineiro e distinguiu as áreas de ocorrência dos arenitos litologicamente semelhantes das Formações Areado e Botucatu. Aquele autor chamou ainda a atenção para o aumento das condições de aridez observadas em direção ao topo da Formação Areado. Ladeira \& Brito (1968) ratificaram essas idéias e interpretaram os seixos facetados do Conglomerado Abaeté como ventifactos, que retratariam um clima deséitico que imperou nos primórdios da sedimentação Areado. Cardoso (1968) também interpretou o Conglomerado Abaeté como produto de paleoclima árido, que teria prevalecido nas áreas periféricas da Bacia do São Francisco, atribuindo idade berrisiana, para a Formação Areado, com base no estudo das fáunulas de conchostráceos presentes em sedimentos lacustres (Membro Quiricó), desta mesma formação.

Braun (1970) e Barbosa et al (1970), com base nos ventifactos, sugeriram paleoclimas desérticos no início da sedimentação Areado, a qual teria ocorrido entre o Aptiano e Albiano, conforme o conteúdo fossilífero desta formação, representado por ostracodes, peixes e plantas. Grossi Sad et al (1971), revendo estudos anteriores sobre as formações cretácicas no Estado de Minas Gerais, acreditaram que estas rochas ocorriam em duas bacias distintas (Bacias do Paraná e do São Francisco), separadas por uma faixa de terrenos pré-cambrianos. De maneira análoga aos autores prévios, atribuíram paleoclimas desérticos para os primórdios da deposição da Formação Areado, com base nos ventifactos do Conglomerado Abaeté. Ladeira et al (1971), baseados nos ventifactos do Abaeté, concordaram com as interpretações paleoambientais acima mencionadas para o início da sedimentação Areado.

Petri (1983) e Suguio \& Barcelos (1983) são outros que atribuem paleoclima deséitico ao início da sedimentação Areado, com base em evidências mostradas pelo Conglomerado Abaeté.

Sgarbi (1989) estudou 256 ventifactos do Conglomerado Abaeté, e também reconheceu origem eólica para os mesmos, descrevendo, ainda, a ocorrência de arenitos eólicos que afloram em grande extensão na borda oriental do Planalto da Mata da Corda, nas cabeceiras do Rio Abaeté. Estes arenitos, objeto deste estudo, situam-se no topo da Formação Areado. 


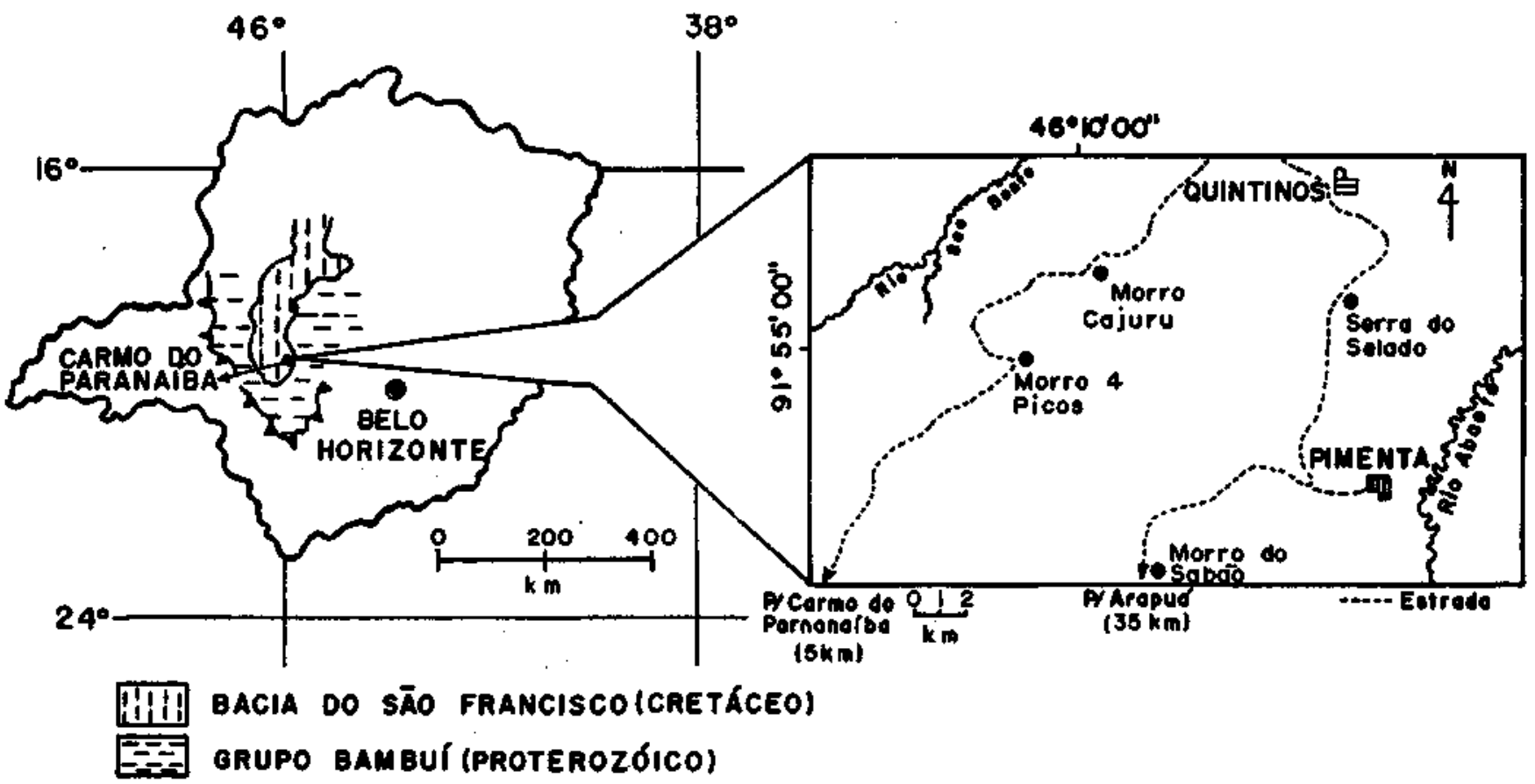

Figura 1 - Mapa de localização da área estudada

Figure 1 - Location map of the studied area

CONDICIONAMENTO GEOLÓGICO A Formação Areado representa a unidade litoestratígráfica basal da Bacia do São Francisco e inicia-se com conglomerados fluviais contendo ventifactos (Membro Abaeté) depositados em regime torrencial sob clima árido a semi-árido. Estes conglomerados jazem diretamente sobre o embasamento representado por filitos da Formação Paraopeba (Grupo Bambui) e p contato se faz segundo uma discordância angular e erosiva de âmbito regional. Acima do Membro Abaeté ocorre um pacote de siltitos lacustres contendo ostracodes (Membro Quiricó), superposto pelo Membro Três Barras, composto por arenitos eólicos e flúvio-deltaicos, e que tem sido, ao longo do tempo, a mais bem estudada porção da Formação Areado, seja devido ao seu bom estado de preservação contra a ação intempérica, seja pela sua grande distribuição geográfica. $\mathrm{Na}$ área investigada, na borda oriental do Planalto da Mata da Corda, estes arenitos ocorrem de maneira descontínua, variando lateralmente desde corpos tipicamente eólicos até flúvio-deltaicos. A espessura máxima observada na Formação Areado foi de cerca de $100 \mathrm{~m}$, com os arenitos eólicos representando cerca de 30 a $35 \%$ do total.

O topo da Formação Areado exibe uma disconformidade, de âmbito local, que a separa da Formação Mata da Corda - esta, constituída por rochas efusivas ultramáficas e alcalinas (Membro Patos), conglomerados vulcânicos e arenitos vulcânicos (Membro Capacete) e por arenitos argilosos com contribuição vulcânica (Membro Urucuia). A coluna estratigráfica da Bacia do São Francisco é apresentada na figura 2.

MÉTODOS DE INVESTIGAÇ̃̃O Vinte amostras representativas da sedimentação eólica Três Barras, provenientes em sua maioria das imediações do $\mathrm{km} 8$ da Rodovia Pimenta-Arapuá, e também do km 1 da Rodovia Quintinos Carmo do Paranaíba (Fig. 1), foram observadas por microscopia óptica convencional, sendo escolhidas cinco para contagens de pontos (500 pontos por lâmina).

Análises químicas de rocha total por espectrometria de plasma (ICP) foram realizadas nesses arenitos eólicos e em seus produtos diagenéticos (silcretes e calcretes). Investiga- ção por microscopia eletrônica de varredura (MEV) foi relizada na determinação de feições eólicas na superfície de grãos de quartzo, assim como na investigação mineralógica e textural de arenitos eólicos e silcretes, utilizando microscópio JEOL-JXA/840 A, equipado com sistema de dispersão por raios X (EDS). Análises por microssonda eletrônica (MSE) foram executadas no estudo de feldspatos potássicos detríticos e autigênicos, estes últimos presentes como cimento nos arenitos eólicos, utilizando sonda JEOL-733, equipada com quatro espectrômetros e detector de electrons secundários (BSE).

Dados relativos às análises mineralógicas por difratometria de raios X (DRX) foram obtidos por meio de difratômetro RIGAKU-RV 200Z, utilizando radiação $\mathrm{CuK} \alpha$.

CARACTERIZAÇÃO EÓLICA Os arenitos eólicos afloram ao longo de quase toda a área investigada; porém, seus termos mais característicos localizam-se ao sul e imediações da localidade de Pimenta (Fig. 1), onde afloram dunas com estratificações cruzadas de grande porte com base tangencial, sobrepondo-se tanto aos arenitos flúvio-deltaicos da mesma unidade, como ao embasamento, às seqüências pelíticas lacustres Quüicó e às conglomeráticas fluviais Abaeté. São arenitos quartzosos, com expressiva contribuição de líticos metamórficos (cerca de $20 \%$ em contagem modal), além de minerais pesados (magnetita principalmente), perfazendo cerca de $4,5 \%$, pelo mesmo método acima descrito. Texturalmente, mostram níveis milimétricos e claros de areias médias a grossas, subarredondadas a arredondadas, compostas por quartzo mono e policristalino, além de fragmentos arredondados de metapelitos, intercalados com outros níveis róseos, formados por areia fina a muito fina, angulosa, composta por quartzo e opacos. Segundo Moraes \& Raja Gabaglia (1986), esta textura parece desenvolver-se nas faces frontais das dunas, locais onde são depositadas nuvens de grãos em suspensão devido à perda súbita de energia eólica, a qual é logo retomada em um processo relacionado ao regime irregular dos ventos, que juntamente com a variação granulométrica presente na área fonte, origina a alternância das lâminas grossas e finas observadas. 

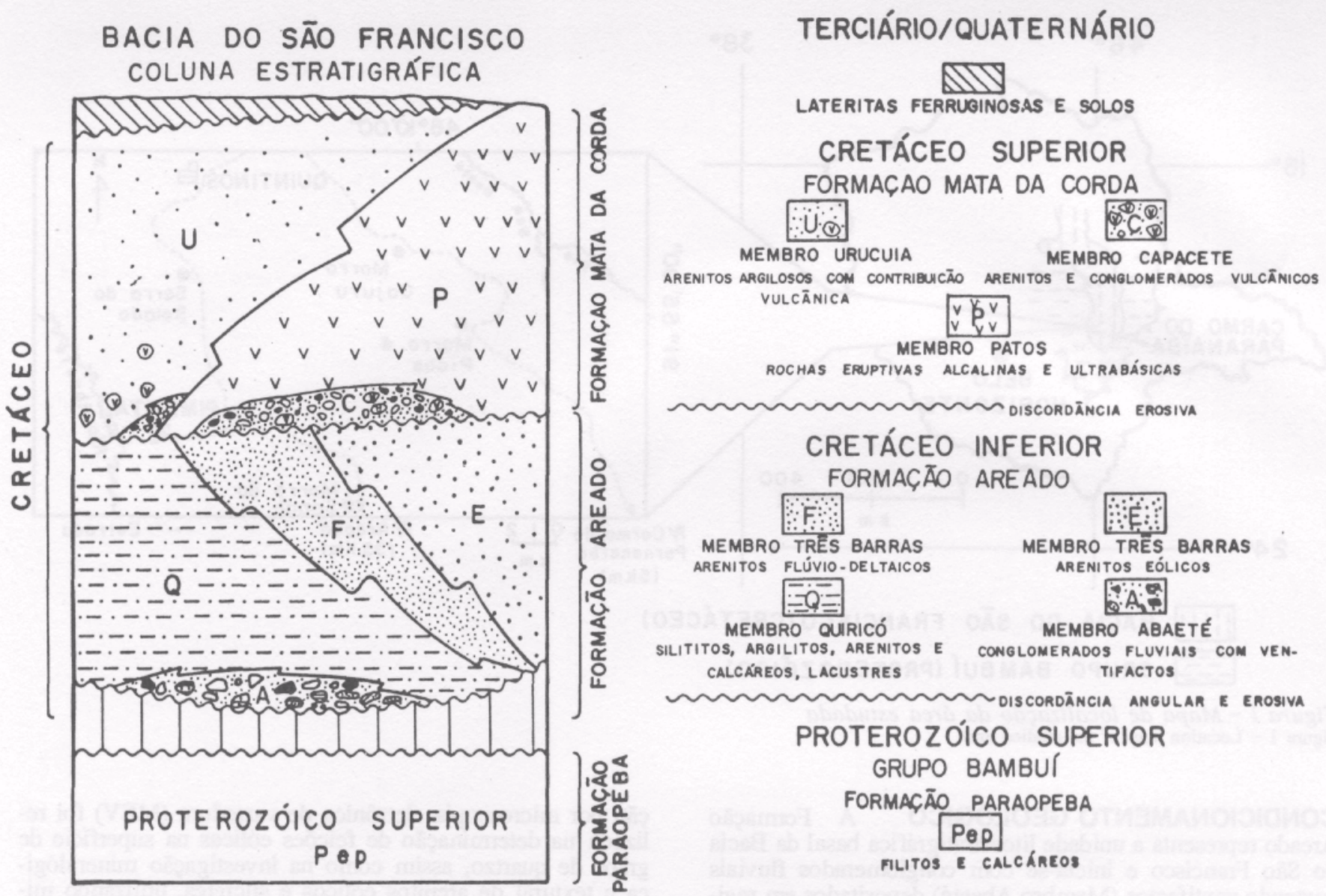

Figura 2 - Coluna estratigráfica da Bacia do São Francisco na área estudada Figure 2 - Stratigraphical column of the São Francisco Basin in the studied area

Um fato notável é a aparência exibida por muitos grãos de quartzo policristalino presentes nas lâminas grossas que, provavelmente por efeitos abrasives, exibem, ao serem observados no campo, coloração branca-leitosa, conferindo à rocha falso aspecto arcosiano.

Ocorrem também, subordinadamente, arenitos maciços, constituídos pelos mesmos grãos grossos arredondados, resultantes de deposição por arrasto e contendo em seus interstícios grãos angulosos, finos, transportados por saltação e que preencheram os espaços intergranulares disponíveis.

Em tennos geomorfológicos, os arenitos eólicos do Membro Três Barras ocorrem quase sempre formando escarpas abruptas que se sobressaem na topografia, devido à maior resistência à erosão dessas rochas em relação às adjacentes. Nesses locais, toma-se difícil estabelecer critérios para uma interpretação genética segura, devido tanto à ausência de exposições tridimensionais como também pela própria dificuldade na coleta de amostras, uma vez que, nesta situação, estes arenitos encontram-se freqüentemente cimentados por sflica. Entretanto, eles podem também ocorrer isoladamente, formando corpos alongados que mostram grandes conjuntos de estratificações cruzadas acanaladas ou tabulares, com dimensões que variam de menos de um até $50 \mathrm{~m}$ de comprimento, limitados por outros conjuntos eólicos segundo superfícies de truncamento abruptas (Foto 1).

Em um conjunto de dunas com estratificacões cruzadas acanaladas situado nas imediações do $\mathrm{km} 8$ da rodovia Pimenta-Arapuá (Fig. 1), verificou-se a presença de camadas com inclinações que variaram de $19 \mathrm{E}$, nas partes superiores e médias das dunas, até valores em torno de $12^{\circ}$, em suas partes basais, local onde os planos de acamamento são tan-

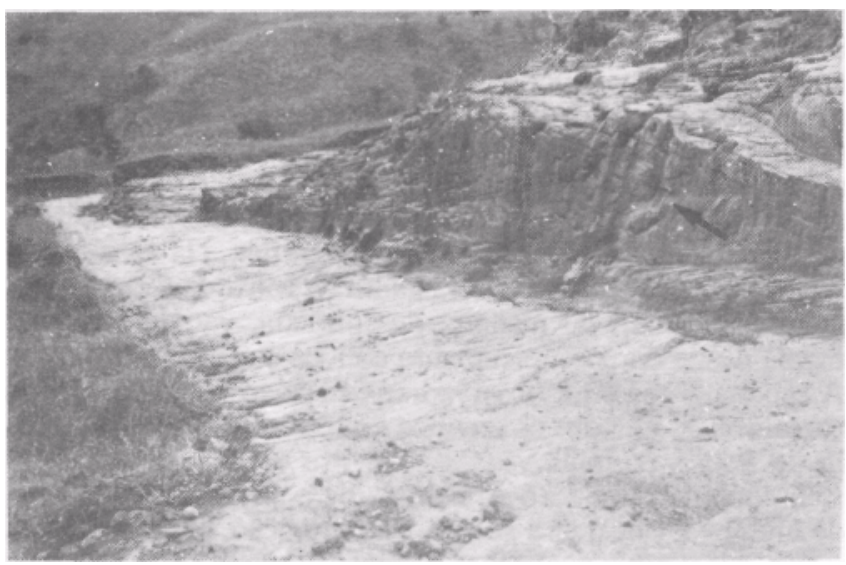

Foto 1 - Arenitos eólicos com estratificações cruzadas tangenciais de grande porte. Notar o truncamento abrupto das camadas perto da escala (martelo) indicado pela seta. Morro do Sabão, município de Arapuá

Photo 1 - Large tangential cross-bedding in eolian sandstones. Note wedgeshaped sets indicated by hammer (arrow). Sabão Range, Arapuá Town

genciais ao pacote sotoposto. Valores de ângulos de mergulho em dunas eólicas medidos por Knight (1929 apud Steidtman, 1974) mostram que, nos arenitos eólicos da Formacão Cásper (Carbonífero e Permiano da Bacia de Laramie, EUA), 75\% dos mergulhos em estratificações cruzadas encontram-se entre $10^{\circ}$ e $25^{\circ}$, com valores médios em torno de $18^{\circ}$. Aquele autor mostra que tais arenitos não exibem mergulhos compatíveis 
com o ângulo máximo de repouso para areias $\left(34^{\circ}\right)$, ângulo este observado em dunas recentes. Como também tais valores angulares não foram observados nas dunas eólicas do Membro Três Barras, deve-se mencionar o fato de que Walker \& Harms (1972 apud Steidtmann 1974) atribuíram a ausência de altos mergulhos em arenitos eólicos antigos à compactação pósdeposicional, como também pela relativa ausência de tais ângulos nas partes basais de dunas antigas e modernas, os quais ocorrem preferencialmente ao longo de suas cristas. Como as partes basais de dunas antigas são as que têm maiores probabilidades de preservação por não estarem em contato direto com os fenômenos erosivos superficiais, estratificações cruzadas de alto ângulo são difíceis de serem observadas em depósitos eólicos antigos.

$\mathrm{O}$ estudo em semidetalhe de um horizonte sotoposto a um conjunto de estratificações cruzadas de grande porte (Foto 2) mostrou, da base para o topo, marcas onduladas seguidas por horizontes contendo lâminas deformadas convolutas, mostrando pseudo-anticlinais de topos achatados ou contorcidos. Tais feições estão relacionadas à deformação plástica por expulsão súbita de água intergranular devido a recalque diferencial. Estas estruturas têm sido observadas em vários tipos de arenitos, inclusive eólicos (McKee et al. 1971, SeUey 1982). Areias eólicas podem tornar-se úmidas, como conseqüência direta de chuvas, pela flutuação do lençol freático e por ascensão capilar de água subterrânea em regiões com altas taxas de evaporação.

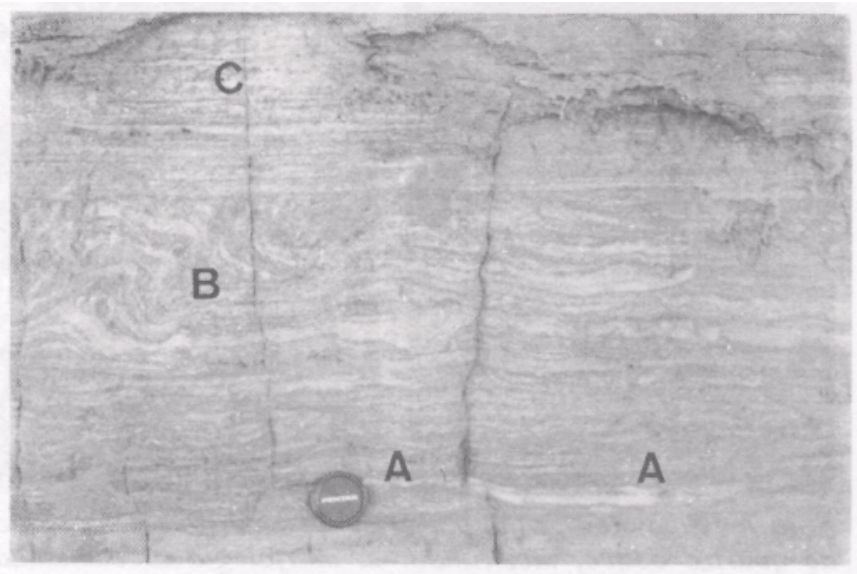

Foto 2 - Detalhe em perfil vertical em arenito eólico: $\boldsymbol{A}$. marcas onduladas; $\boldsymbol{B}$. deformações convolutas; $\boldsymbol{C}$. laminação paralela. Morro do Sabão, município de Arapuá Photo 2 - Details in vertical profile of eolian sandstone. A. ripple marks; B. convolute deformations; C. parallel laminations. Sabão Range, Arapuá Town

O topo da feição mostrada exibe um conjunto de lâminas horizontais não-deformadas, contendo as mesmas características texturais anteriormente citadas, ou seja, intercalações de lâminas claras de areia média arredondada com outras roscas de areia fina a muito fina, angulosa e contendo magnetita. Estas últimas são responsáveis pela coloração rósea devido à liberação, pelos minerais opacos, de hidróxidos de ferro por diagênese, segundo processos desenvolvidos em climas desérticos e descritos por Walker (1967 a, b), Walker \& Honea (1969), Walker et al (1978).

Os sentidos de transporte indicados pelas estratificações cruzadas mostram grande variação - a maioria indica fluxo para norte. Entretanto, vários afloramentos mostram transporte para leste-nordeste e ainda para sudoeste. Variações nos sentidos dos ventos são comuns em ambientes desérticos, conforme atestam dados fornecidos por McKee \& Tibbitts (1964), os quais estudaram em detalhe estruturas de dunas presentes no deserto tíbio e citaram mudanças radicais nessas direções em um único dia.

Os arenitos ora investigados exibem formas de diaclasamento colunar, na forma de prismas pseudo-hexagonais, semelhantes a disjunção colunar de efusivas básicas. Elas ocorrem tanto no plano do acamamento (Foto 3) como em seções verticais englobando várias camadas, com dimensões que variam de poucos até $80 \mathrm{~cm}$. Bjomberg et al. (1964) descreveram feições similares no arenito eólico silicificado Botucatu, tendo atribuído sua origem à desidratação da rocha por compactação ou por diagênese durante a cristalização da silica amorfa intergranular, anteriormente coloidal.

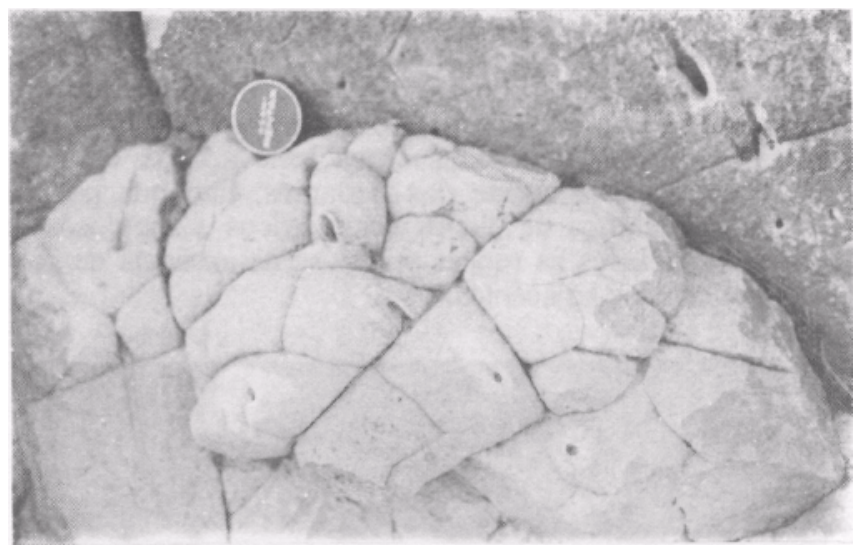

Foto 3 - Feição morfológica superficial observada nos arenitos eólicos Três Barras. Morro do Sabão, município de Arapuá

Photo 3 - Morphological features showed by Três Barras eolian sandstones. Sabão Range, Arapuá Town

No km 1,5 da Rodovia Quintinos-Carmo do Paranaíba (Fig. 1), verificou-se nítido contato entre esta fácies eólica e o embasamento pré-cambriano representado por filitos (Grupo Bambuí), sendo o contato angular e erosivo (Foto 4).

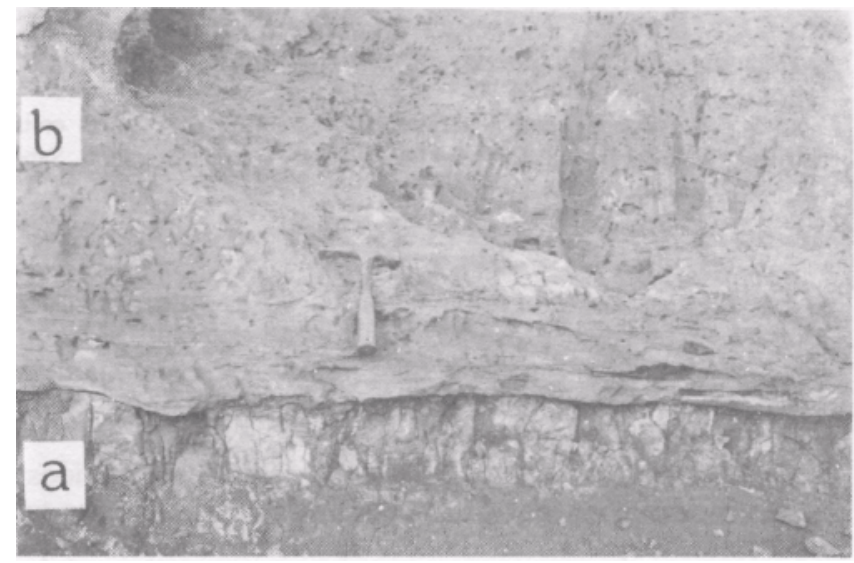

Foto 4 - Discordância angular e erosiva entre: a. metapelitos da Formação Paraopeba, Grupo Bambuí; b. arenito eólico Três Barras, Formação Areado. Serra do Selado, município de Carmo do Paranaíba

Photo 4 - Angular unconformity between: a. phyllites from Paraopeba Formation, Bambuí Group; b. eolian sandstones from Três Barras Member, Areado Formation. Selado Range, Carmo do Paranaíba Town

Nesta interface ocorre um nível centimétrico e contínuo de areias cimentadas por hidróxidos de ferro (ferricretes), localmente cristalizados como goethita. Esta particularidade reflete as condições diversas de permeabilidade existente entre 
os arenitos e os metapelitos subjacentes, estes últimos comportando-se como uma barreira impermeável à percolação vertical de águas meteóricas ferruginosas provenientes das partes superiores do pacote arenoso. Esses níveis de ferricretes refletem, provavelmente, a existência de um clima quente e seco; porém, com épocas esporádicas de relativa umidade, implantado em época posterior à sedimentação eólica.

Quando o pacote eólico encontra-se em contato com as rochas da Formação Mata da Corda, estratigraficamente a ele sobreposta, observaram-se duas situações: a. melhor preservação dos arenitos eólicos pela proteção exercida pelas rochas efusivas que atuam como uma barreira protetora à percolação vertical de águas meteóricas; e b. presença de estruturas de deformação atectônica devidas tanto a processos relacionados com recalque diferencial pelo peso das lavas e pelos conglomerados vulcânicos sobrepostos (Foto 5), como também, possivelmente, devido à expansão súbita dos fluidos intergranulares das areias submetidas à brusca elevação da temperatura decorrente do aporte dos derrames, fato que poderia explicar a presença de blocos decimétricos e angulosos de arenito, associados às rochas eruptivas na ausência de condutos vulcânicos adjacentes.

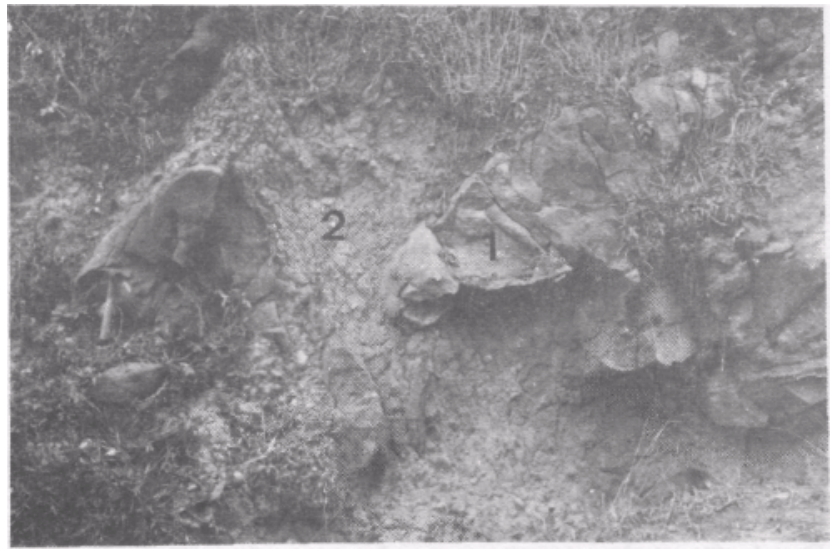

Foto 5 - Deformação por recalque diferencial: 1. arenito eólico Três Barras; 2. rochas efusivas do Membro Patos, Formação Mata da Corda. Morro do Sabão, município de Ar apua

Photo 5 - Deformation due to differential charge: 1. Três Barras eolian sandstone; 2. lavas from Patos Member, Mata da Corda Formation. Sabão Range, Arapuá Town

Fragmentos de tamanhos variados do arenito eólico encontram-se também presentes nas rochas epiclásticas sobrejacentes (Foto 6), situação que mostra o posicionamento estratigráfico deste arenito, em contato erosivo com o Arenito Urucuia (Formação Mata da Corda).

Grãos de quartzo de origem eólica foram submetidos a estudo morfológico por MEV, visando detectar feições texturais microscópicas consideradas típicas de tal sedimentação. A Foto 7a mostra, com pequeno aumento, o bom grau de arredondamento e esfericidade presentes em um grã̃o com dimensão situada entre areia média a grossa, proveniente das lâminas grossas da rocha. Sua superfície é fosca, com as grandes irregularidades suavizadas pela abrasão eólica. Aumento maior (Foto $7 \mathrm{~b}$ ) mostra feições relacionadas com polimento eólico, como por exemplo em sua parte centre-inferior, onde aparecem pequenas fraturas limitadas por lineações convexas, consideradas típicas de grãos eólicos, denominadas "upturned fracture plates"', e descritas na literatura por Krinsley \& Donahue (1968), Margolis \& Krinsley (1971), Krinsley et al (1976) e Baker (1976). A parte central desta foto mostra um fraturamento primário sendo obstruído por deposição de

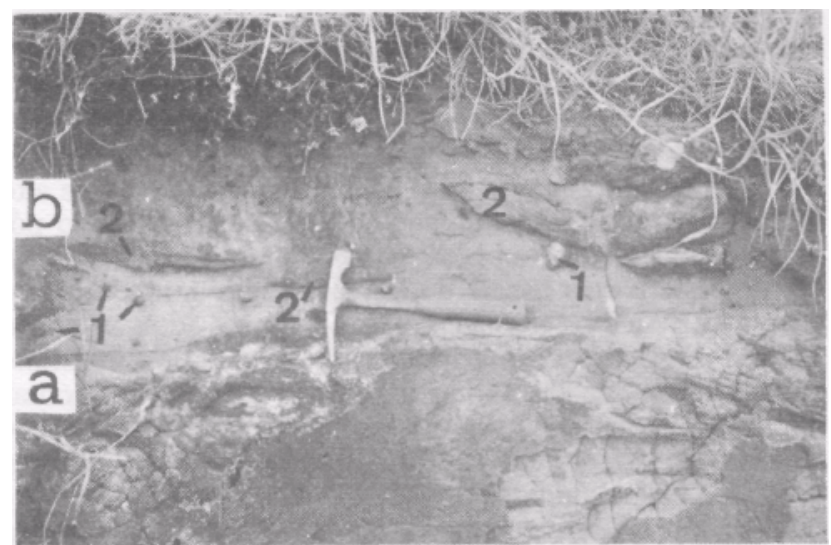

Foto 6 - Contato erosivo mostrando: a. arenito eólico Três Barras, Formação Areado; b. arenito com contribuição vulcânica Urucuia, Formação Mata da Corda. 1. fragmentos de rochas vulcânicas; 2. fragmentos angulosos do arenito eólico Três Barras. Serra do Selado, município de Carmo do Paranaíba

Photo 6 - Erosional contact: a. eolian Três Barras sandstone; b. volcanic sandstone from Urucuia Member, Mata da Corda Formation. 1. volcanic rock fragments; 2. Três Barras eolian sandstone fragments. Selado Range, Carmo do Paranaíba Town
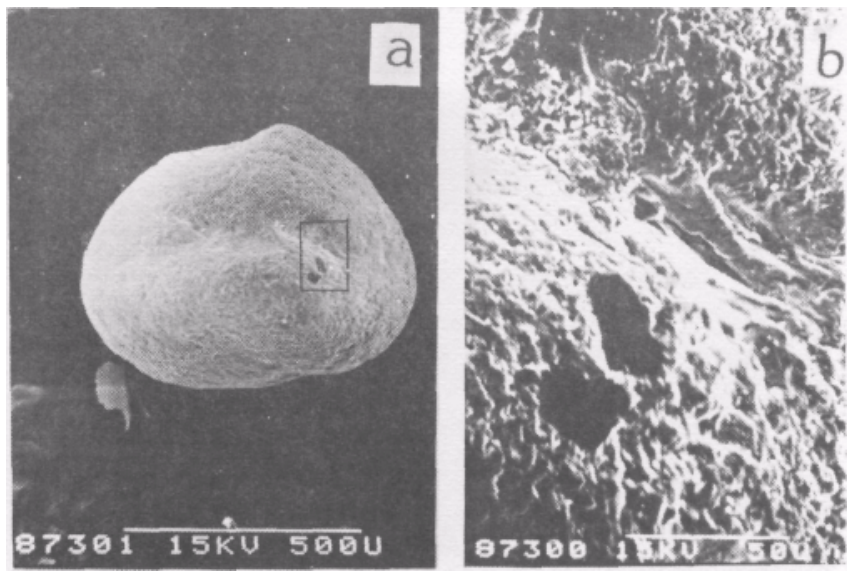

Foto 7 - Fotomicrografia por MEV da superficie de um grão de quartzo eólico, mostrando: a. morfologia arredondada do grão e superfície fosca característica; $\boldsymbol{b}$. grande aumento da área em destaque da foto $7 a$, mostrando microfraturamentos típicos, presentes na parte inferior da foto, e recobrimento dos mesmos por silica autigênica na parte superior. As áreas escuras são inclusões de turmalina. Serra do Selado, município de Carmo do Paranaíba Photo 7 - SEM photomicrographis of eolian quartz grain showing: a. wellrounded morphology and frosted appearence; $b$. higher magnification of the area outlined in photo 7a, exhibiting typical eolian microfractures. Note also turmaline inclusions. Selado Range, Carmo do Paranaíba Town

silica autigênica. Algumas fraturas secundárias desenvolveram-se durante este crescimento secundário. Notam-se dois pontos escuros representando inclusões de turmalina preta, presente em muitos grãos eólicos observados.

PETROGRAFIA E MINERALOGIA Os arenitos eólicos do Membro Três Barras mostraram também, em lâminas delgadas, alternância de leitos constituídos por grãos grossos, claros, com aqueles compostos por finos, róseos, resultantes de deposição por queda de grãos na face a sotavento da duna (Foto 8). As dimensões médias dos grãos grossos e bem arredondados estão em torno de $0,45 \mathrm{~mm}$. Os grãos finos, angulosos, mostraram dimensões médias de $0,12 \mathrm{~mm}$. 


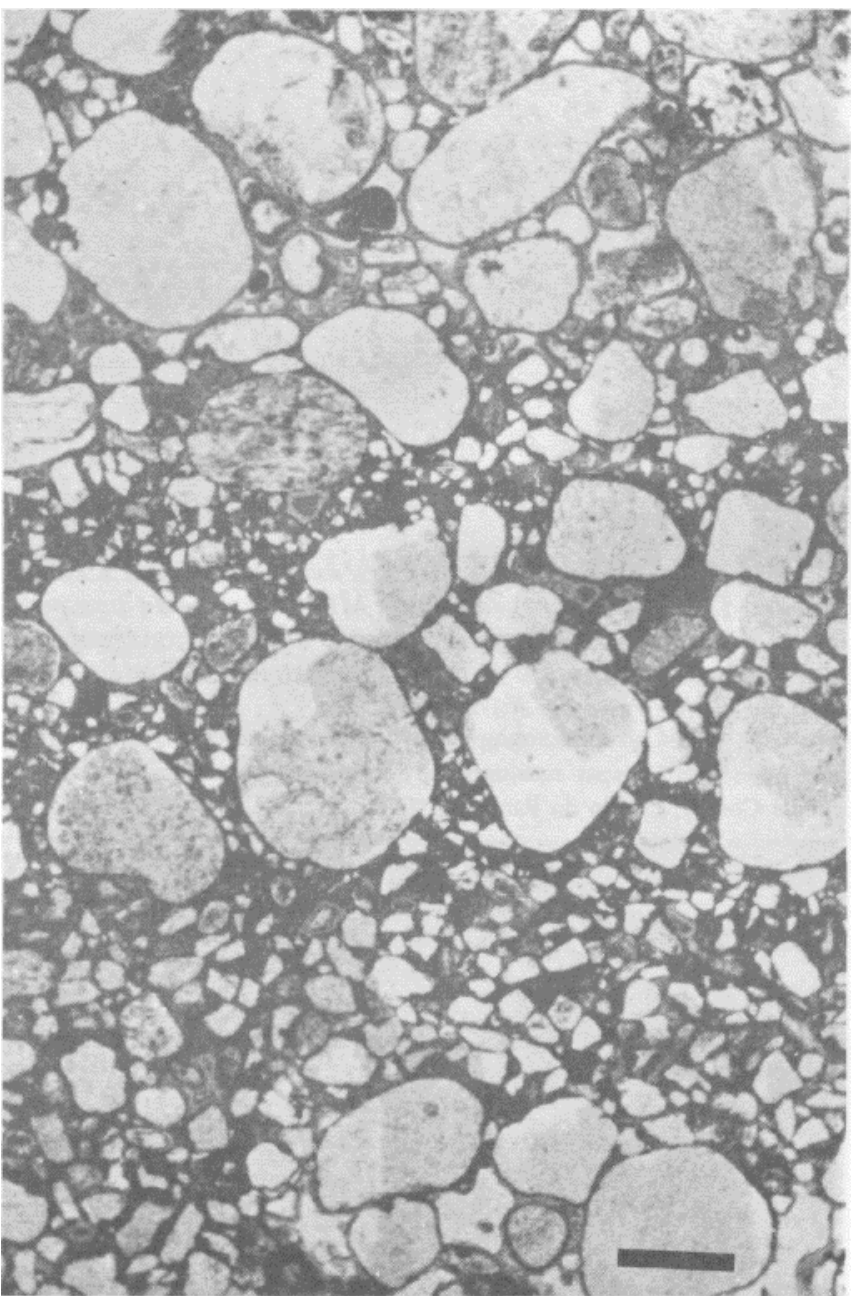

Foto 8 - Textura eólica mostrando intercalações de lâminas com grãos grossos, arredondados, com outras com grãos finos e angulosos, com magnetita. Distrito de Pimenta, municipio de Carmo do Paranaíba. Fotomicrografia, nicóis descruzados. Escala de barra $=0,22 \mathrm{~mm}$ Photo 8 - Typical eolian bimodal texture showing coarse rounded grains interlayered with fine angular grains. Pimenta County, Carmo do Paranaíba Town. Photomicrograph, uncrossed nicols. Bar scale $=0.22 \mathrm{~mm}$

Os minerais pesados presentes (principalmente nos leitos finos) são magnetita, com turmalina e rutilo subordinados.

Contagens de pontos em lâminas delgadas desses arenitos mostraram valores médios de $63 \%$ de quartzo monocristalino; $16,1 \%$ de fragmentos líticos, principalmente metassiltito e süex; $7,3 \%$ de material argiloso intersticial; $6,1 \%$ de feldspato potássico (microclínio, ortoclásio); $5,5 \%$ de quartzo policristalino e $2 \%$ de minerais opacos, com magnetita predominando. $\mathrm{O}$ material argiloso intersticial, investigado posteriormente por DRX, revelou a presença de illita e caulinita; e quando observado por MEV, mostrou a presença de feldspatos potássicos autigênicos, dispostos como cobertura por sobre grãos detríticos de quartzo e feldspato, assuntos estes que serão detalhados adiante.

A microscopia óptica mostrou também a presença de argilas associadas a óxidos de ferro, dispostas como cutículas (coatings) anisópacas e irregulares sobre os grãos detríticos, indicando uma origem ligada a infiltração mecânica. Processos como estes ocorrem em clima árido a semi-árido, onde o lençol freático é profundamente rebaixado periodicamente. Aguaceiros torrenciais e esporádicos, carreando finos, infiltram-se na rocha por gravidade e depositam argilas nas su- perfícies dos grãos detríticos em um processo eminentemente mecânico. Feições análogas foram estudadas pioneiramente por Crone (1975), em aluviões recentes do sudoeste dos Estados Unidos e noroeste do México.

Estudos por DRX realizados na fração argila destes arenitos mostraram: a. a presença de illita e caulinita, em quantidades equivalentes provenientes de uma amostra pouco alterada intempericamente, originária da base do pacote eólico. $\mathrm{O}$ local, situado no km 10 da rodovia Pimenta-Arapuá (Fig. 1), possui espessa cobertura de rochas eruptivas da Formacão Mata da Corda; e b. a presença unicamente de caulinita, proveniente de uma amostra muito alterada intempericamente, originária da base do pacote eólico, sem capeamento, em afloramento situado no km 1,5 da rodovia Quintinos-Carmo do Paranaíba (Fig. 1).

A presença de cauliniia normalmente relaciona-se com a transformação, por intemperismo químico, do feldspato. Esta transformação implica na adição de $\mathrm{H}_{2} \mathrm{O}$ e retirada de $\mathrm{K}^{+}$e $\mathrm{SiC}_{2}$, podendo ocorrer na diagênese precoce ou mesmo no intemperismo. A illita, quando relacionada com processos de infiltração mecânica em clima árido a semi-árido, pode ter sua origem ligada à transformação diagenética de esmectitas para interestratificados illita-esmectita e, finalmente, para illita (Blatt 1979, De Ros 1986).

Os dados indicam a tendência que favorecem a maior participação de caulinita nas partes mais alteradas do arenito eólico, e que o grau de alteração destes arenitos é menor onde existe capeamento por rochas vulcânicas, as quais inibem a percolação vertical de águas meteóricas devido ao seu comportamento relativamente impermeável.

DIAGÊENESE A diagênese que afetou os arenitos eólicos Três Barras relaciona-se com processos que atuaram na superfície da crosta ou muito próximos a ela. Este estágio precoce de diagênese (eodiagênese, segundo Choquette \& Pray 1970) relaciona-se com a circulação de águas superficiais carreando materiais em solução e suspensão. Neste caso, foram detectadas as seguintes feições diagenéticas:

Arenitos Eólicos Amostras provenientes das partes basais e médias do pacote eólico, ora investigado e localizado nas imediações do $\mathrm{km} 8$ da rodovia Pimenta-Arapuá (Fig. 1), mostraram, ao serem analisadas por $\mathrm{MEV}$, a presença de cimentação por feldspatos potássicos autigênicos, os quais ocorrem na forma de cristais euédricos, com dimensões variando entre cinco e dez um, recobrindo grãos detríticos de quartzo e feldspato. Associados, ocorrem também aglomerados anédricos de argilominerais bastante alterados intempericamente, provavelmente originados por infiltração mecânica. Morfologicamente, os cristais de feldspatos potássicos autigênicos aparecem como pequenos romboedros (Foto 9) ou pseudolosângos, estes últimos exibindo combinação de pinacóide basal (001) com prisma (110), com a face (010) pouco desenvolvida ou ausente (Foto 10), forma esta denominada "hábito da adularia" por Baskin (1956). Esta cimentação autigênica pode recobrir total ou parcialmente a superfície dos grãos detríticos, reduzindo consideravelmente a porosidade original da rocha (Foto 11).

A ocorrência de feldspatos potássicos autigênicos em sedimentos requer a presença de íons potássio, silicato e alumínio no ambiente diagenético. Walker et al. (1978), estudando uma assembléia de minerais autigênicos (incluindo feldspatos potássicos) presentes em sedimentos continentais do sudoeste dos EUA. mostraram que a autigênese relacionava-se com a alteração e dissolução de grãos de silicates detríticos por soluções intraestratais alcahnas. No presente caso, análises executadas por microssonda eletrônica (MSE) indicaram a presença de feldspatos potássicos detríticos dissolvidos seletivamente segundo a orientação de suas macias (Foto 12), em um processo denominado dissolução incon- 


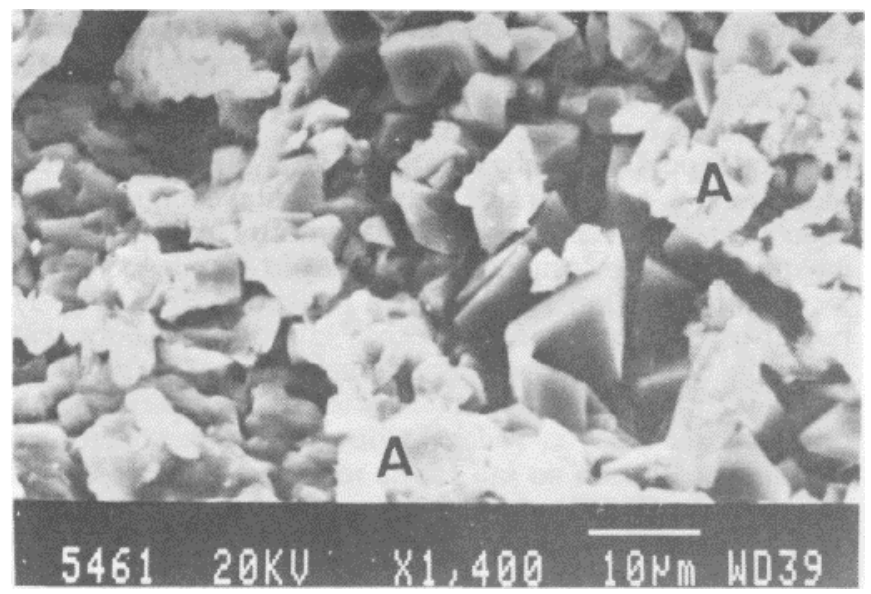

Foto 9 - Fotomicrografia por MEV mostrando cristais de feldspato potássico autigênico, que ocorrem recobrindo grãos detríticos de quartzo e feldspato potássico. Associados, ocorrem aglomerados de argilominerais (A) degradados por intemperismo. Distrito de Pimenta, município de Carmo do Paranaíba

Photo 9 - SEM photomicrograph showing authigenic potassium feldspar recovering detrital quartz and feldspar. Clay minerals undentified (A) also are present, Pimenta County, Carmo do Paranaíba Town

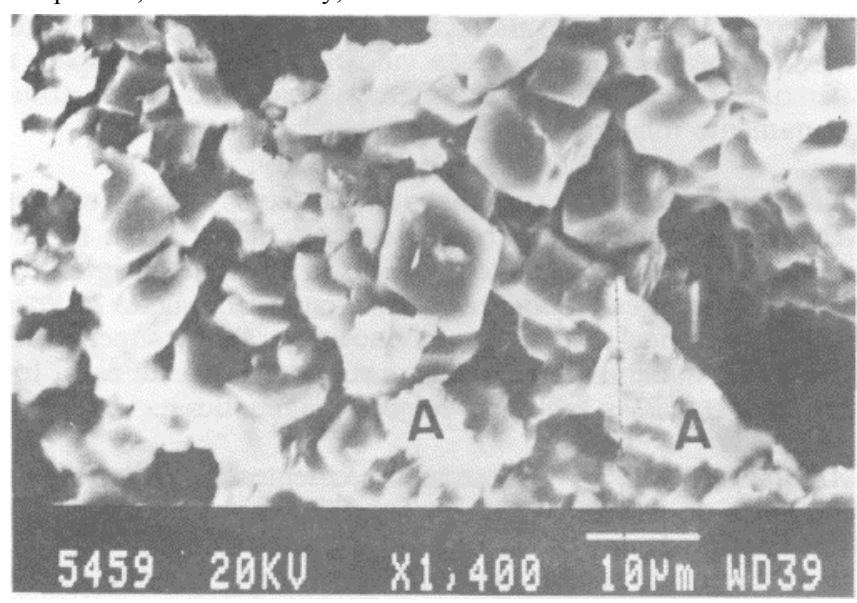

Foto 10 - Fotomicrografia por MEV mostrando cristais autigênicos de feldspato potássico na forma de romboedros (ortoclásio) e pseudo-losângos (adularia). Associados, encontram-se argilominerais degradados por intemperismo (A). Distrito de Pimenta, município de Carmo do Paranaíba Photo 10 - SEM photomicrograph showing authigenic potassium feldspar with rhombohedral (ortoclase) and flattened (adularia) shapes. Undentified clay minerals (A) are also present, Pimenta County, Carmo do Paranaíba Town

gruente, descrito por vários autores como por exemplo Pettijohn et al. (1987). Neste caso, a situação é sugestiva no sentido de se considerar os feldspatos potássicos detríticos como a fonte principal dos íons necessários à precipitação dos feldspatos potássicos autigênicos.

Análises químicas quantitativas, realizadas por MSE, permitiram conhecer a composição molecular destes feldspatos potássicos autigênicos, revelando sua alta pureza química (Or $>97,5 \mathrm{~mol} \%$ ), complementada por teores subordinados de albita e anortita. Além do cálcio, que entra na rede cristalina do feldspato potássico autigênico pela substituição conjugada (cálcio e alumínio substituindo süica e potássio), formando fases subordinadas de anortita, o sódio substitui o potássio gerando albita. Quantidades também pequenas de ferro in e bário encontram-se presentes pela substituição simples do alumínio e potássio, respectivamente.

O sistema ortoclásio-albita-anortita, presente nos feldspatos potássicos autigênicos do arenito eólico Três Barras, pode

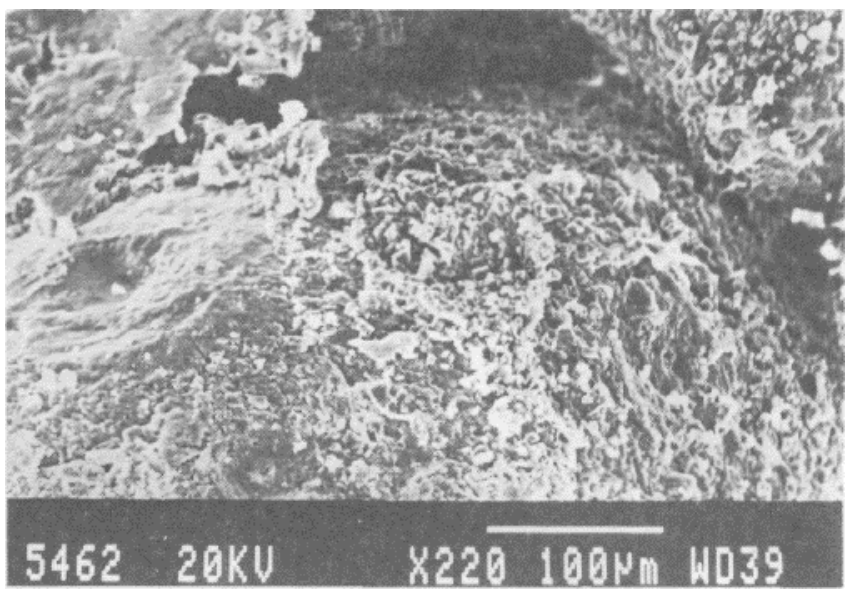

Figura 11 - Fotomicrografia por MEV mostrando u aspectu geral dos grãos detríticos de quartzo e feldspato, recobertos por feldspato potássico autigênico. Distrito de Pimenta, municipio de Carmo do Paranaíba

Photo 11 - SEM photomicrograph showing general aspects of detrital quartz and potassium feldspar surrounded by authigenic potassium feldspars. Pimenta County, Carmo do Paranaíba Town

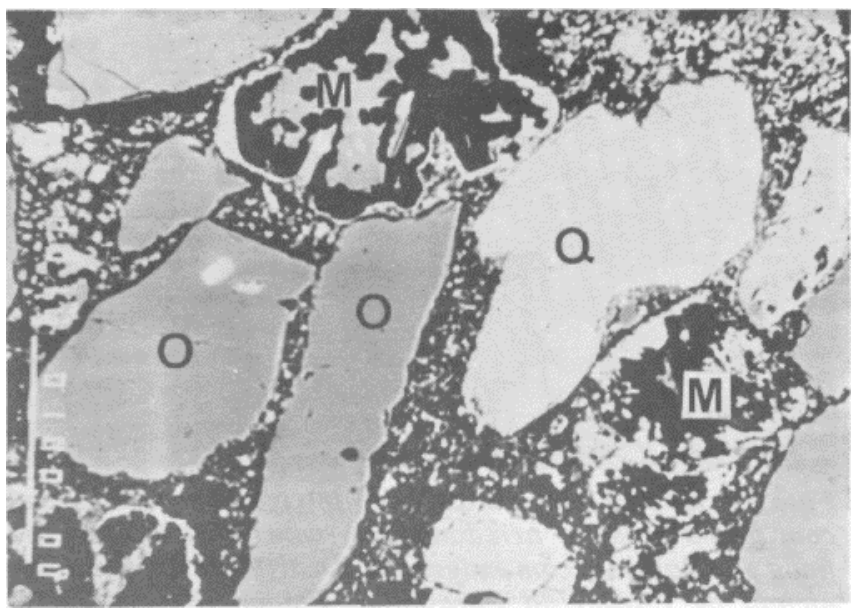

Foto 12 - Fotomicrografia por microssonda eletrônica (MSE) (elétrons secundários), mostrando grãos detríticos de microclínio dissolvidos seletivamente (M) ao longo de suas macias, além de quartzo e ortoclásio detríticos, circundados por pequenos cristais de feldspato potássico autigênico. Morro do Sabão, município de Arapuá. Escala de barra $=100$ $\mu m$

Photo 12 - Electronic microprobe photomicrograph with backscatter electron detector (BSE) showing seletive dissolution along the twin's planes of detrital

ser exemplificado por meio de cinco análises efetuadas, cujos resultados médios foram: $\mathbf{O r}=98,2 \mathrm{~mol} \% ; \mathbf{A b}=1,7 \mathrm{~mol} \%$; An $=0,1 \mathrm{mo} / \%$. Estes resultados são compatíveis com aqueles descritos por Morad et al. . (1989), referentes a análises químicas por MSE em feldspatos potássicos autigênicos, presentes em arenitos triássicos da Espanha (Or > 99,0 mol\%), considerados estequiometricamente $\mathrm{KalSi}_{3} \mathrm{O}_{8}$. Outras cinco análises, executadas por MSE em feldspatos potássicos detríticos do arenito eólico Três Barras, mostraram os seguintes resultados médios: $\mathbf{O r}=94,5 \mathrm{~mol} \% ; \mathbf{A b}=5,3 \mathrm{~mol} \% ; \mathbf{A n}=$ $0,2 \mathrm{~mol} \%$. Esse fato ilustra a conhecida tendência de minerais de alta temperatura (detríticos) incorporarem quantidades maiores de cations extras devido ao seu maior espaçamento reticular com relação aos autigênicos. Nesse sentido, Kastner \& Siever (1979), em um trabalho clássico sobre a ocorrência de feldspatos potássicos autigênicos em rochas sedimentares, comentam sobre a alta pureza química desses minerais de baixa temperatura, gerados em ambientes superficiais, em contato com a circulação de água meteórica. 
Outra fonte potencial para o aporte, por intemperismo químico, de süica, alumínio e potássio ao meio diagenético local, são as rochas da Formação Mata da Corda, constituídas por efusivas de filiação alcalina e ultramáfica, além de arenitos vulcânicos e conglomerados vulcânicos, sobrepostos aos arenitos eólicos ora estudados. Análises químicas de rocha total realizadas nestas rochas efusivas revelaram teores médios de 4,0\% de $\mathrm{K}_{2} \mathrm{O}$ (Sgarbi 1991). Assim, também a presença de esmectita na fração argilosa das rochas da Formação Mata da Corda, revelada por DRX (Sgarbi 1989), assume grande importância, pois ela pode indicar o processo geoquímico através do qual o potássio em solução é incorporado a uma nova assembléia de minerais estáveis, como os feldspatos potássicos autigênicos considerados.

Kastner \& Siever (1979) descreveram a reação química que pode ocorrer em um meio diagenético de baixa temperatura, contendo $\mathrm{SiO}_{2}, \mathrm{~K}_{2} \mathrm{O}, \mathrm{Al}_{2} \mathrm{O}_{3}, \mathrm{Na}_{2} \mathrm{O}$ e $\mathrm{H}_{2} \mathrm{O}$ ), com a conseqüente formação de feldspato potássico a partir da esmectita.

$\begin{array}{cl}\begin{array}{c}\text { esmectita de sódio } \\ \text { e alumínio }\end{array} & \begin{array}{c}\text { feldspato } \\ \text { potásico }\end{array} \\ \mathrm{Na}\left(\mathrm{Al} \mathrm{I}_{5} \mathrm{Mg}\right) \mathrm{Si}_{12} \mathrm{O}_{30}(\mathrm{OH})_{6}+5 \mathrm{~K}^{+}+3 \mathrm{H}_{4} \mathrm{SiO}_{4} & -5 \mathrm{KAlSi}_{3} \mathrm{O}_{8}+8 \mathrm{H}_{2} \mathrm{O}+2 \mathrm{H}^{+}+\mathrm{Na}^{+}+\mathrm{Mg}^{++}\end{array}$

O mecanismo de transporte envolvido na redistribuição dos elementos, necessário à precipitação dos feldspatos potássicos autigênicos enfocados, parece relacionar-se com a movimentação dos fluídos intergranulares da rocha na qual os íons são transportados em solução. Esta hipótese parece adaptar-se mais às características físicas da rocha, como alta porosidade original (devido à ausência de grandes espessuras de rochas capeantes e material fino intergranular), além de sua exposição à circulação de águas meteóricas.

Silcretes Os arenitos eólicos Três Barras podem, localmente, apresentar cimentação por silica nos estados criptocristalino e amorfo, originando silcretes. Estas rochas têm sido pouco descritas na literatura por autores americanos e europeus; a maior parte dos trabalhos tem sido levada a efeito por autores do hemisférico sul, principalmente australianos, neo-zelandeses e sul-africanos, como por exemplo Williamson (1957), Stephens (1971), Smale (1973) e Oehler (1976). Os silcretes Três Barras apresentam uma textura maciça, constituída principalmente por grãos detríticos de quartzo e feldspato potássico cimentado por silica, a qual pode constituir cerca de $22 \%$ em volume da rocha. Os grãos são médios a finos, bem arredondados a subangulosos, exibindo poucos contatos entre si. A porosidade da rocha foi totalmente preenchida por sílica amorfa, com núcleo criptocristalinos representados por calcedônia fibrorradiada. Ocasionalmente, ocorrem concentrações de opala preenchendo fraturas na rocha, as quais, ao serem analisadas por DRX, mostraram a presença de zonas com alta cristalinidade (picos bem desenvolvidos, característicos de quartzo, tridimita-alfa e cristobalita-alfa). Tal fato parece indicar a atuação dos processos diagenéticos na rocha, os quais comandam a evolução da sílica a partir da opala- A (amorfa), em direção à opala CT (criptocristalina, formada por cristobalita e tridimita), calcedônia, e quartzo, sua forma cristalina mais estável.

Ao serem investigados por MEV, os silcretes Três Barras mostraram grande variedade de feições relacionadas com a cimentação autigênica da süica. Pequenas esf érulas, com diâmetros variando de três a seis um dispostas isoladamente tanto por sobre a superfície dos grãos detríticos de quartzo como por sobre o cimento silicoso, mostraram, quando aumentadas significativamente, serem formadas por minúsculas concreções arredondadas, compostas unicamente por sílica (Fotos 13a, b), conforme dados analíticos fornecidos pelo EDS acoplado ao MEV. Feições semelhantes, com diâmetros de cerca de $1 \mu \mathrm{m}$, presentes em vazas diatomáceas da Geórgia (EUA), foram descritas por Pollard \& Weaver (1973), sendo classificadas como esferas opalinas e interpretadas como tendo sido formadas em vazios inacessíveis a outros íons, como o alumínio, magnésio e ferro. Como as aqui analisadas, aquelas esférulas exibem alto grau de pureza química, sendo relacionadas geneticamente com a presença abundante de géis de sílica no meio diagenético.

Foram também observadas esférulas de cristobalita, denominadas comumente de lepisferas, que ocorrem tanto em conjuntos superpostos a grãos detríticos de quartzo, como em feições isoladas ocupando os espaços intergranulares associadas ao cimento silicoso, com dimensões que variam de 10 a $90 \mu \mathrm{m}$ (Fotos 13c, d).

Feições análogas foram descritas por Meyer \& Reis (1983) em silcretes mesozóicos de Portugal e também Tucker (1985) descreveu lepisferas dü cristobalita em rochas eocênicas do Golfo Pérsico.

Outras feições observadas nas superfícies de grãos de quartzo foram plaquetas pseudo-hexagonais com dimensões em torno de $7 \mu \mathrm{m}$, cujos centros exibem vazios circulares. Estas
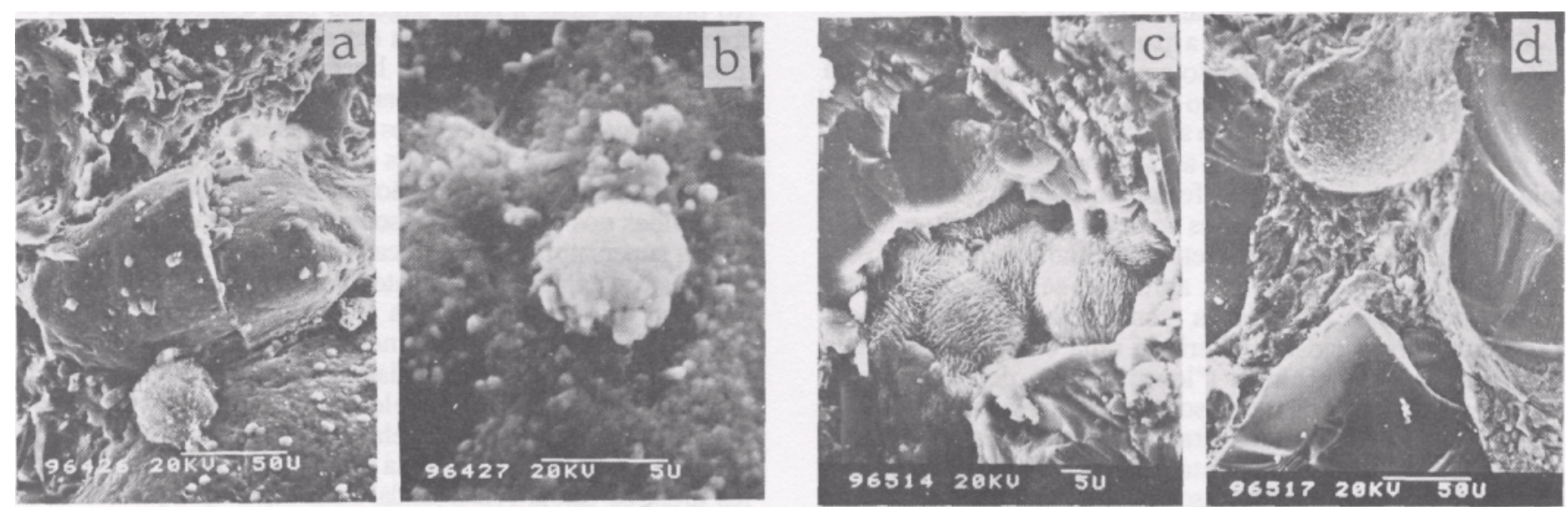

Foto 13 - Foto mie rografia por MEV em silcretes Três Barras mostrando: a. grão de q-lartzo fraturado em cimento silicoso, recoberto parcialmente por esférulas microscópicas de sílica autigênica; $\boldsymbol{b}$. detalhe de uma microesférula de sílica autigênica, formada por aglutinação de outras esférulas menores; c. conjunto de lepisferas de cristobalita autigênica ocupando vazios no cimento silicoso do silcrete; $\boldsymbol{d}$. lepisfera de cristobalita autigênica no cimento silicoso entre dois grãos de quartzo fraturados. Morro dos Quatro Picos, município de Carmo do Paranaíba

Photo 13 - SEM photomicrograph of Três Barras silcretes showing: a. fractured quartz grain cemented by authigenic silica, recovered by silica microspheres; b. silica microsphere framework; c. assembly of authigenic cristobalite lepisferes filling space of the sileceous cement; d. cristobalite lepisfere above the intragranular sileceous cement. Quatro Picos Range, Carmo do Paranaíba Town 
formas sugerem ser o modo pelo qual a sflica secundária é remobilizada da superfície do grão detrítico de quartzo subjacente. Associados também à cimentação silicosa, ocorrem minerais de argila fibrosos, que pela morfologia e paragênese sugerem ser sepiolita ou palygorskita (Fotos 14a, b).
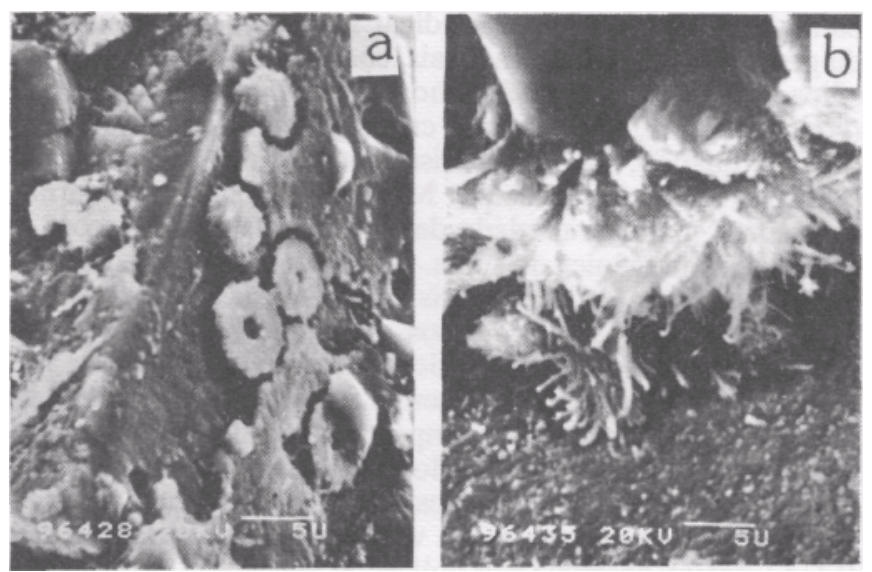

Foto 14 - Fotomicrografias por MEV em silcretes Três Barras mostrando: a. plaquetas pseudo-hexagonais de silica sobre a superficie de um grão detrítico de quartzo; $\boldsymbol{b}$. argilominerais fibrosos (sepiolita?palygorskita?) sobre grão de quartzo detrítico. Morro dos Quatro Picos, município de Carmo do Paranaíba

Photo 14 - SEM photomicrographs of the Três Barras silcretes, showing: a. pseudo-hexagonal sheets of silica on detrital quartz grain; $\mathbf{b}$. fibrous clay mineral (sepiolite? palygorskite?) on detrital quartz grain. Quatro Picos Range, Carmo do Paranaíba Town

Análises químicas de rocha total (Tab. 1), executadas em arenitos eólicos não-cimentados por süica (coluna l, amostras coletadas da parte média do pacote eólico e provenientes do $\mathrm{km} 10$ da rodovia Pimenta-Arapuá) e em silcretes Três Barras (coluna 2, amostras originárias do topo do pacote eólico do mesmo local anterior) tiveram seus resultados comparados com dados descritos por Williamson (1957), referentes a sedimentos silicificados australianos (coluna 3).

Os dados mostraram que, a partir dos arenitos eólicos e silcretes Três Barras, chegando aos silcretes australianos, há um progressivo enriquecimento em $\mathrm{SiO}_{2}$ e uma perda contínua de $\mathrm{Al}_{2} \mathrm{O} 3, \mathrm{Fe}_{2} \mathrm{O}_{3}$ e $\mathrm{K}_{2} \mathrm{O}$. Tal fato sugere a retirada, por lixivição, de minerais menos resistentes ao intemperismo, como argilominerais, minerais opacos e feldspato potássico respectivamente, originalmente presentes no sedimento pré-cimentado.

O titânio presente nos silcretes Três Barras, quando observado por microscopia óptica, apresenta-se como concentrações amareladas (associadas com manchas ferruginosas castanho-avermelhadas), sugerindo uma origem relacionada com estruturas coloformes ("leucoxênio"), depositadas por soluções coloidais em processos semelhantes ao da silica. $\mathrm{O}$ titânio faz parte dos óxidos altamente resistentes à lixiviação e, comumente, tende a aumentar sua participação relativa em rochas silicificadas. Neste caso, nota-se um enriquecimento em $\mathrm{TiO}_{2}$ nos silcretes australianos, com relação aos do Membro Três Barras.

Vários autores (Woolnough 1930, Frankel \& Kent 1937, Frankel 1952 e Du Toit 1954 apud Smale 1973) comentam as condições ambientais associadas às grandes ocorrências de silcretes no mundo. Estas rochas formam-se onde a drenagem é pobre, sendo a flutuação do lençol de água, causada por alternância de períodos secos e úmidos, um importante fator a ser considerado. Stephens (1971) sugere que muitos silcretes
Tabela l-Análises químicas de rocha total por espectrometria de plasma (ICP). Si e $\mathrm{Na}$ dosados separadamente. $\mathrm{Fe}_{2} \mathrm{O}_{3}$ = ferro total; $P P C=$ perda por calcinação. 1. Arenitos eólicos Três Barras, média de três análises da parte média do pacote eólico; 2. Silcretes Três Barras, média de três análises da parte superior do pacote eólico; 3. Silcretes australianos, média de seis análises, segundo Williamson (1957); 4. Calcretes Três Barras, média de três amostras da parte superior do pacote eólico; 5. Arenitos vulcânicos do Membro Capacete, Formação Mata da Corda, média de três análises Table I - Total rock chemical analyses by ICP. Determination of Si and $\mathrm{Na}$ separately made. Total iron as $\mathrm{Fe}_{2} \mathrm{O}_{3}, \mathrm{PPC}=$ igneous loss. 1 . Average of three analyses of eolian Três Barras sandstones; 2 . Average of three analyses of Três Barras silcretes; 3. Average of six analyses of Australian silcretes, after Williamson (1957); 4. Average of three analyses of Três Barras calcretes; $\mathbf{5}$. Average of three analyses of volcanic sandstones (Capacete Member, Mata da Corda Formation)

\begin{tabular}{l|c|c|c|r|r}
\hline AMOSTRAS & 1 & 2 & 3 & 4 & 5 \\
\hline & $\%$ & $\%$ & $\%$ & $\%$ & $\%$ \\
$\mathrm{SiO}_{2}$ & 84,36 & 87,30 & 97,06 & 50,44 & 29,95 \\
$\mathrm{Al}_{2} \mathrm{O}_{3}$ & 6,14 & 4,17 & 0,39 & 1,22 & 2,98 \\
$\mathrm{Fe}_{2} \mathrm{O}_{3}$ & 2,31 & 1,97 & 0,39 & 0,86 & 12,89 \\
$\mathrm{~K}_{2} \mathrm{O}$ & 5,11 & 3,38 & 3,03 & 0,88 & 3,63 \\
$\mathrm{CaO}$ & 0,06 & 0,14 & - & 22,48 & 19,97 \\
$\mathrm{Na} 2 \mathrm{O}$ & 0,08 & 0,23 & 0,00 & 0,67 & 0,12 \\
$\mathrm{MgO}$ & 0,68 & 0,43 & 0,03 & 1,29 & 4,76 \\
$\mathrm{MnO}$ & 0,09 & 0,13 & - & 0,01 & 0,32 \\
$\mathrm{P}_{2} \mathrm{O}_{5}$ & 0,00 & 0,08 & - & 0,13 & 1,11 \\
$\mathrm{TiO}_{2}$ & 0,49 & 0,33 & 0,78 & 0,13 & 7,09 \\
$\mathrm{PPC}^{\mathrm{Total}}$ & 1,46 & 1,17 & 0,05 & 19,94 & 16,27 \\
$\mathrm{TiO}_{2} / \mathrm{SiO}_{2}$ & 100,78 & 99,34 & 98,73 & 98,05 & 99,09 \\
& 0,006 & 0,004 & 0,008 & - & - \\
\hline
\end{tabular}

na Austrália foram formados a partir da liberação da sflica durante a formação de lateritos.

Com relação à origem da sflica presente nesses silcretes, sabe-se que, no caso de arenitos cimentados em subsuperfície, a fonte disponível da silica relaciona-se com a dissolução do quartzo pelo aumento da pressão gerando soluções de pressão (pressure solution, segundo Pittman 1972 apud Blatt 1979), assim como a liberação da sílica durante a diagênese dos argilominerais, geralmente em profundidades significativas. No presente caso, a fonte sugerida para a sílica relaciona-se com processos desenvolvidos em superfície ou muito próximos a ela, envolvendo a sua liberação pelas próprias areias eólicas em ambiente árido a semi-árido. Nesse sentido, devese mencionar os experimentos levados a efeito por Foumier (1960 apud Siever 1962), nos quais o autor demonstrou experimentalmente que a abrasão entre as partículas quartzosas envolvidas nos processos de sedimentação pode produzir soluções supersaturadas em sílica. Também, Paraguassu (1972) demonstrou experimentalmente a possibilidade da cimentação da sílica oriunda de arenitos friáveis eólicos da Formação Botucatu cimentando estes mesmos arenitos, em processos de circulação de água destüada em sistema fechado e submetidos a calor. Segundo aquele autor, a sílica é facilmente remobilizada dos arenitos pela água circulante, podendo-se supor que pelo menos parte da silicif icação observada naqueles arenitos esteja relacionada com a precipitação da sflica por circulação da água intergranular.

Os silcretes mostram, ainda, oxidação pós-deposicional de ferro, envolvendo os grãos detríticos de quartzo e feldspato (principalmente microclínio). A presença de ferro é importante porque ele reduz a solubilidade da sflica, proporcionando sua precipitação. Outros fatores importantes no controle da cimentação por sílica são a concentração destes elementos no meio circulante, assim como a redução do $\mathrm{pH}$ em ambiente altamente alcalino para valores inferiores a nove (Smale 1973). 
Segundo De Ros \& Moraes (1984), em condições de diagênese avançada, a dissolução do quartzo parece estar essencialmente controlada pela temperatura, em função dos altos valores de alcalinidade necessários ao processo $(\mathrm{pH} \sim$ 10). Em condições superficiais, entretanto, a dissolução do quartzo parece ser controlada mais intensamente pela variação do $\mathrm{pH}$, que, nestas condições, pode facilmente chegar a valores altamente alcalinos $(\mathrm{pH} \sim 10)$, conforme mostraram estudos desenvolvidos por Oppenheimer \& Master (1965 apud Multer \& Hoffmeister 1968).

A temperatura naturalmente exerce a sua influência no processo, uma vez que os valores da solubilidade do quartzo em água a $25^{\circ} \mathrm{C}, 50^{\circ} \mathrm{C}$ e $100^{\circ} \mathrm{C}$ são de 6 a 10,21 e 62 ppm, respectivamente. Na temperatura de $25^{\circ}$, cristobalita e tridimita alcançam 27 ppm, e a sflica amorfa de 100 a 140 ppm (Siever 1957, Arbey 1980, Williams et al. 1985).

Calcretes Os arenitos eólicos Três Barras sofreram, localmente, intensa cimentação carbonática. Seus produtos são representados por arenitos quartzosos cujos interstícios foram totalmente preenchidos por carbonato de cálcio, formando mosaicos grossos e equigranulares de calcita espática ou por cristais gigantes e alongados, dispostos subparalelamente (Foto 15)

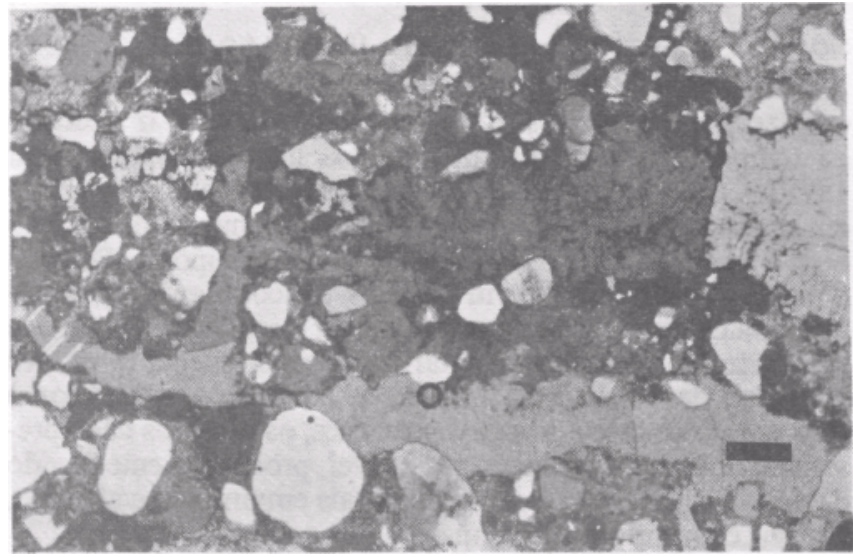

Foto 15 - Textura poiquilotópica em calcrete Três Barras. Notar grandes cristais de calcita na parte inferior da foto. Morro do Cajuru, município de Carmo do Paranaíba. Foto mie rog $r$ afia, nicóis cruzados. Escala de barra $=0,4 \mathrm{~mm}$ Photo 15 - Poikilotopic texture in Três Barras calcrete. Note intergranular large calcite crystals. Cajuru Hill, Carmo do Paranaíba Town. Photomicrograph, crossed nicols. Bar scale $=0.4 \mathrm{~mm}$

A cimentação carbonática é uma feição freqüentemente observada na Formação Areado, afetando tanto o conglomerado basal Abaeté e os pelitos lacustres Quiricó, como os arenitos flúvio-deltaicos e eólicos Três Barras. Entretanto, é nestes termos eólicos que o processo se implantou mais intensamente, imprimindo amplas modificações na rocha original, feições estas observáveis tanto em afloramentos como também em seções delgadas. De uma maneira mais abrangente, o carbonato de cálcio presente em grande extensão na Formação Areado tem sua origem provavelmente a partir da dissolução intempérica das muitas lentes de calcário presentes no embasamento local (Grupo Bambuí). Localmente, esta cimentação atinge grande intensidade, chegando a modificar totalmente a textura e estrutura da rocha hospedeira, sugerindo, nestes casos, uma origem localizada para o carbonato. Nesse sentido, cabe descrever um dos locais mais significativos da área investigada para esta cimentação, tanto em volume de material introduzido como na intensidade das modificações observadas na rocha impregnada.
Trata-se de uma elevação com algumas dezenas de metros de altura (Morro Cajuru), que se sobressai bruscamente por sobre os terrenos arrasados do embasamento, localizando-se no km 13 da rodovia Quintinos - Carmo do Paranaíba (Fig. 1). O morrote inicia-se com a seqüência pelítica Quiricó, a qual contém localmente, em sua base, delgados leitos do conglomerado Abaeté. Sobrepondo-se aos pelitos, ocorrem níveis de arenitos fluviais vermelhos, finos, sotopostos a um pacote de arenitos eólicos róseos, médios, pertencentes ambos ao Membro Três Barras. Em seguida, formando a elevação mais conspícua do morro, ocorrem rochas eruptivas ultramá-

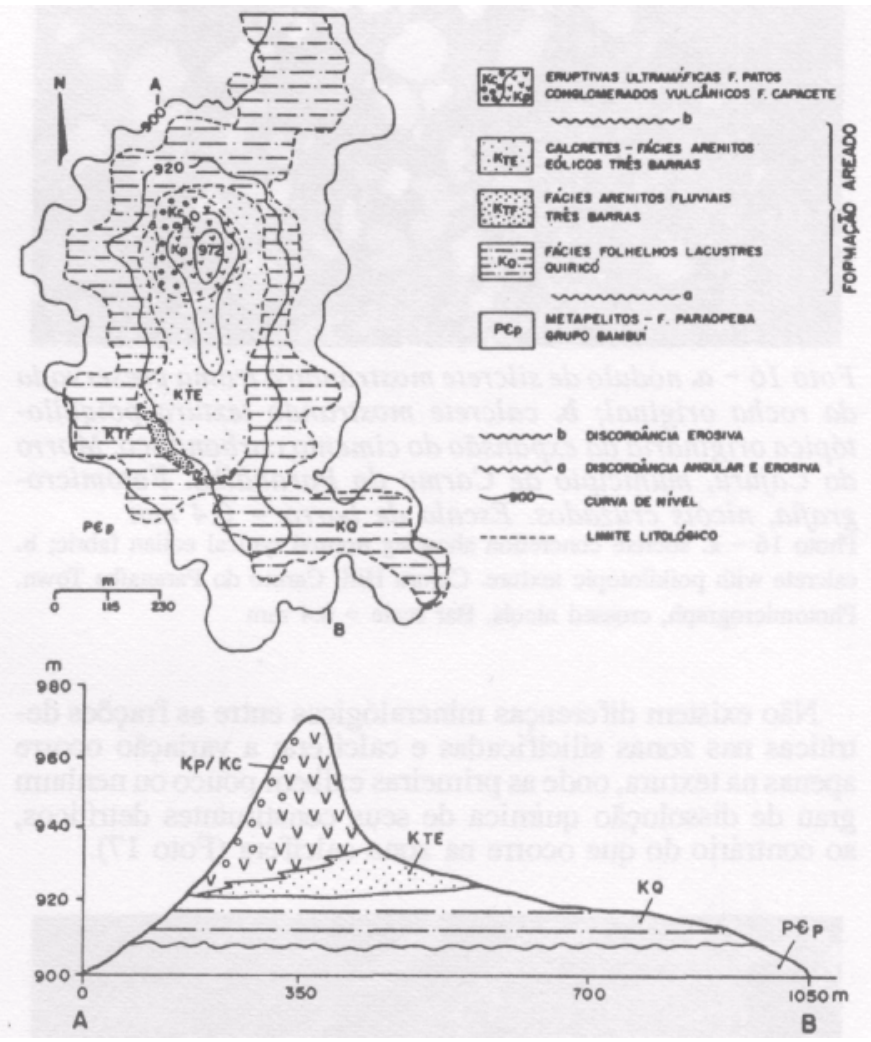

Figura 3 - Mapa geológico do Morro Cajuru, local tipo dos calcretes Três Barras $\left(K_{T F}\right)$, e seção $A-B$ mostrando a disposição dos calcretes sotopostos às rochas vulcânicas e epiclásticas da Formação Mata da Corda. Município de Carmo do Paranaiba

Figure 3 - Geological map of Cajuru Hill showing calcrete distribution in eolian Três Barras sandstones ( $\mathrm{K}_{\mathrm{TE}}$ ), and A-B cross section showing calcretes underlying volcanic and epiclastic rocks of Mata da Corda Formation. Carmo do Paranaíba Town

ficas associadas a conglomerados vulcânicos. Todas as rochas presentes no local contém impregnação por carbonato de cálcio (Fig. 3), inclusive o topo do embasamento.

Sabe-se que, ao contrário dos arenitos marinhos cimentados por calcita, a qual se origina da compactação e desidratação de folheíhos associados (De Ros \& Moraes 1984), a cimentação localizada e intensa que afetou partes do Membro Três Barras parece relacionar-se com a liberação do cálcio a partir da alteração intempérica das rochas vulcânicas e epiclásticas sobrejacentes. A ocorrência dos arenitos cimentados por calcita (calcretes), dispostos grosseiramente circundantes ao mencionado corpo central magmático e epiclástico, e o aumento em carbonato de cálcio nos sedimentos em direção ao centro do morro corrobora tal hipótese. Análises químicas realizadas por Sgarbi (1991) em rochas vulcânicas do referido morro indicam teores médios de $15 \%$ e $8 \%$ de óxidos de cálcio e magnésio, respectivamente, confirmando o potencial da rocha como agente fornecedor dos materiais cimentantes. 
Os calcretes Três Barras mostraram, ao serem investigados por petrograf ia óptica, a ocorrência de nódulos isolados, constituídos por silcretes, interpretados como testemunhos do arenito anteriormente silicificado, cujo cimento foi posteriormente substituído por calcita (Foto 16).

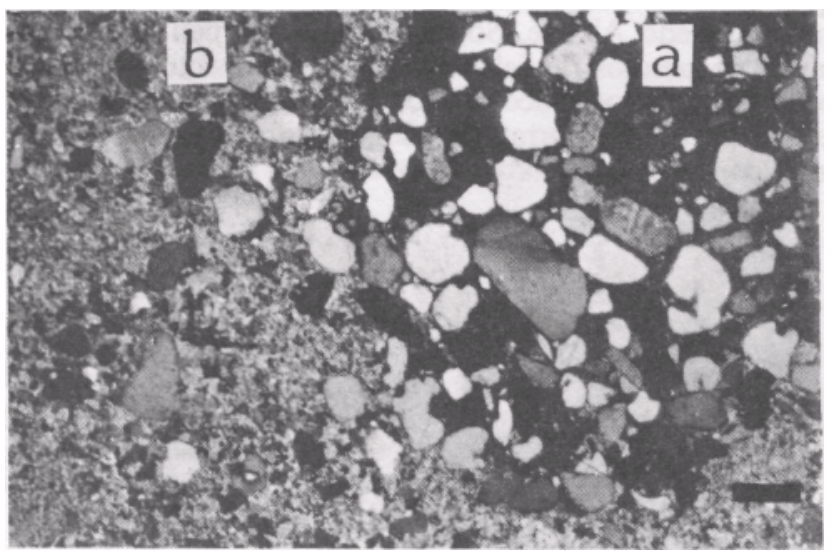

Foto 16- a. nódulo de silcrete mostrando a trama preservada da rocha original; $\boldsymbol{b}$. calcrete mostrando textura poiquilotópica originária da expansão do cimento carbonático, Morro do Cajuru, município de Carmo do Paranaíba. Fotomicrografia, nicóis cruzados. Escala de barra $=0,4 \mathrm{~mm}$ Photo 16 - a. silcrete concretion showing normal typical eolian fabric; $b$. calcrete with poikilotopic texture. Cajuru Hill, Carmo do Paranaíba Town. Photomicrograph, crossed nicols. Bar scale $=0.4 \mathrm{~mm}$

Não existem diferenças mineralógicas entre as frações detríticas nas zonas silicificadas e calcífera; a variação ocorre apenas na textura, onde as primeiras exibem pouco ou nenhum grau de dissolução química de seus constituintes detríticos, ao contrário do que ocorre na zona calcífera (Foto 17).

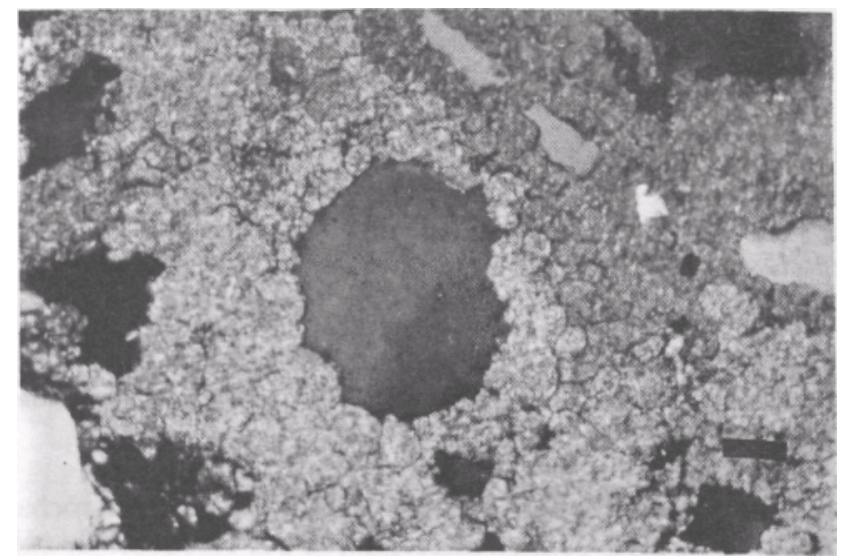

Foto 17 - Calcrete com grãos detríticos de quartzo exibindo bordas dissolvidas. Morro do Cajuru, municipio de Carmo do Paranaiba. Fotomicrografia, nicóis cruzados. Escala de barra $=0,1 \mathrm{~mm}$

Photo 17 - Calcrete showing detrital quartz grain with dissolved borders. Cajuru Hill, Carmo do Paranaíba Town. Photomicrograph, crossed nicols. Bar scale $=0.1 \mathrm{~mm}$

Esta textura, poiquilotópica, definida por cristais grandes de calcita envolvendo outros de quartzo menores, origina uma trama expansiva e proporciona comumente a fragmentação mecânica dos grãos de quartzo pela expansão do cimento calcífero (Foto 18).

A substituição do quartzo é observada tanto nas bordas dos grãos como nas zonas de deformação e fraturamento

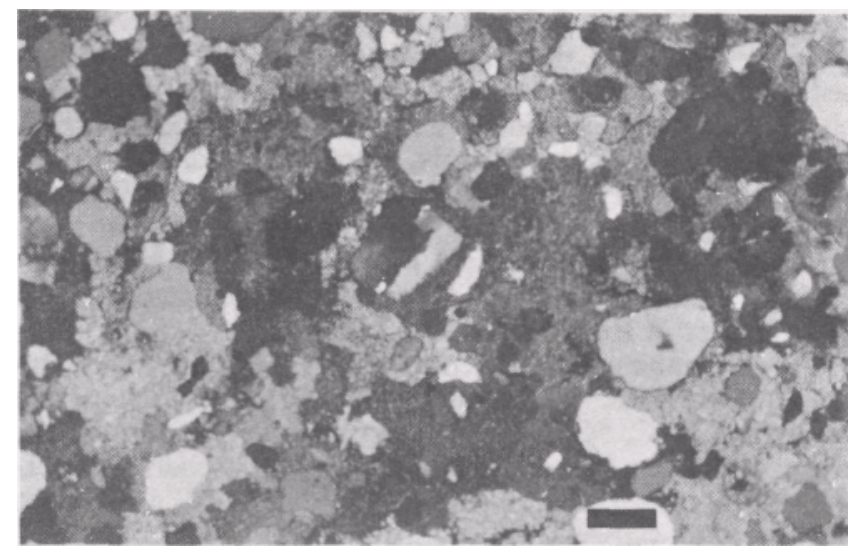

Foto 18 - Textura poiquilotópica em calcrete Três Barras. Morro do Cajuru, município de Carmo do Paranaíba. Fotomicrografia, nicóis cruzados. Escala de barra $=0,4 \mathrm{~mm}$ Photo 18 - Poikilotopic texture of Três Barras calcrete. Cajuru Hill, Carmo do Paranaíba Town. Photomicrograph, crossed nicols. Bar scale $=0.4 \mathrm{~mm}$

exibida pelos grãos policristalinos de quartzo, ocorrendo segundo a reação:

$\mathrm{SiO}_{2}+\mathrm{Ca}^{2}+2 \mathrm{HCO}_{3^{-}}+2 \mathrm{H}_{2} \mathrm{O}-\mathrm{CaCO}_{3}+\mathrm{H}^{+}+\mathrm{HCO}_{3}+\mathrm{H}_{4} \mathrm{SiO}_{4}$

Sabe-se que a estabilização da calcita e a dissolução do quartzo desenvolvem-se preferencialmente com o aumento da temperatura e do $\mathrm{pH}$ dos fluidos intergranulares (Blatt 1979). Como previamente citado, a solubilidade do quartzo em ambiente superficial eleva-se relativamente de modo lento com o aumento da temperatura, podendo-se supor, então, que a dissolução do quartzo em questão, concomitante à precipitação da calcita, relaciona-se mais com o aumento do $\mathrm{pH}$, que pode, em ambiente continental superficial, chegar a valores em torno de 10. Para os feldspatos potássicos, assim como para outros aluminossilicatos presentes, os mesmos não apresentam graus de dissolucão apreciável, provavelmente devido à relativa estabilização destes minerais em ambiente alcalino, em um comportamento similar ao da calcita.

A associação da sflica com carbonato de cálcio tem se mostrado bastante comum em calcretes de todo o mundo. Elas ocorrem em grande extensão na África do Sul, assim como também na Austrália, onde ocorrem horizontes de calcedônia dentro de calcretes (Goudie 1972). Silcretes relacionam-se com a existência de condições de aridez mais severas que aquelas presentes na formação de calcretes. Associações de silcretes e calcretes refletem a existência de oscilações climáticas dentro do regime árido a semi-árido, os quais teriam propiciado a precipitação diferenciada destes materiais.

Pettijohn et al. (1987) descrevem o processo de dissolução e substituição de um mineral por outro. No caso de arenitos com cimentação calcítica, após a instalação do cimento que ocupa toda a porosidade intergranular, inicia-se o processo de substituição por difusão iônica isovolumétrica. No contato entre o grão de quartzo e o cimento calcítico, forma-se uma frente de dissolução, na qual o quartzo é dissolvido com a imediata precipitação da calcita.

Arenitos cimentados por carbonato de cálcio citados na literatura têm sido associados, quase sempre, à presença de discordâncias litológicas, e regidos por processos desenvolvidos na superfície ou muito próximo a ela (Blatt 1979). O presente caso corrobora tais observações, uma vez que os calcretes Três Barras desenvolveram-se no topo do pacote eólico, nível estratigráfico relacionado com a discordância que delimita as Formações Areado e Mata da Corda.

Análises químicas de rocha total (Tab. 1) foram realizadas em calcretes Três Barras (coluna 4, amostras provenientes do Morro do Cajuru) e em arenitos vulcânicos da Formação Mata 
da Gorda, superpostos ao pacote eólico (coluna 5, amostras provenientes do Morro Cajuru e do km 10 da rodovia Pimenta-Arapuá). Foi considerado que a formação dos calcretes a partir dos arenitos eólicos (coluna 1, amostras coletadas na parte média do pacote eólico e provenientes do $\mathrm{km} 10 \mathrm{da}$ rodovia Pimenta-Arapuá) proporcionou o decréscimo da suíça, alumínio e potássio (relacionadas com a lixiviação do quartzo,micas e feldspato potássico respectivamente), além de aumento considerável de cálcio (relacionado à calcita, cimentante da rocha), magnésio (relacionado à dolomita, que ocorre em quantidade bastante subordinada no cimento) e perda ao fogo (PPC, relacionada ao conteúdo $\mathrm{CO}_{2}$ dos carbonates).

O magnésio, relativamente escasso nos'calcretes Três Barras, impede, segundo Folk $(1965,1973)$, o livre crescimento dos cristais de calcita, originando morfologias microcristalinas e f ibrosas, texturas não compatíveis com as normalmente observadas nesses calcretes. De fato, entre 20 amostras laminadas, apenas uma mostrou a presença de pequenos romboedros de dolomita associados a calcita.

Os dados referentes aos arenitos vulcânicos (coluna 5) chamam atenção pelos altos teores de cálcio observados, certamente relacionados com a presença de clinopiroxênios e perovskita. O magnésio relaciona-se com as olivinas, sendo que todos estes minerais encontram-se nos clastos vulcânicos do arenito analisado (Sgarbi 1991).

A análise mostra ainda teores relativamente altos em $\mathrm{TiO}_{2}$, fato que poderia dar ensejo à pesquisa específica sobre a geologia econômica, uma vez que teores acima de $5 \%$ foram detectados em locais distantes entre si em até $50 \mathrm{~km}$. Deve-se mencionar, entretanto, as reduzidas espessuras destas litologias, alcançando no máximo alguns poucos metros, e seu caráter descontínuo de exposição. A origem primária do $\mathrm{TiO}_{2}$ relaciona-se provavelmente a perovskita e anatásio, detectados nos litoclastos vulcânicos analisados e em seus produtos de alteração intempérica, assim como nas lavas associadas. Contribuições decorrentes de ilmenita, apesar de não detectadas, também seriam possíveis, principalmente no caso das rochas epiclásticas.

\section{CONCLUSÕES}

a. Os arenitos relacionam-se, inequivocamente, com o transporte eólico devido a feições típicas amplamente distribuídas na área, como bimodalidade granulométrica, a presença de estratificações cruzadas de grande porte, a ausência de níveis argilosos e a presença de grãos de areia bem arredondados; b. a alteração intempérica e a diagênese geraram caulinita e illita (detectados por DRX), sendo que o primeiro argilomineral parece relacionar-se quantitativamente com o maior grau de alteração da rocha;

c. investigação submicroscópica (MEV) mostrou a presença, nesses arenitos eólicos, de cimento constituído por pequenos cristais de feldspato potássico autigênico com dimensões que variam entre 5 e $10 \mu \mathrm{m}$, que ocorrem recobrindo grãos detríticos de quartzo e feldspato potássico. A hipótese sugerida para a fonte de cations necessários a esta cimentação (sífica, alumínio e potássio) é a dissolução dos feldspato potássico detrítico presente na rocha, não se excluindo, contudo, possíveis contribuições a partir da alteração intempérica das rochas ultramáficas e alcalinas sobrejacentes. Análises químicas realizadas por microssonda eletrônica em feldspato potássico autigênico mostraram que o mesmo possui alta pureza química (Or $>97,5$ mol\%) em contraposição aos valores encontrados nos feldspatos detríticos $($ Or $>94,0 \mathrm{~mol} \%)$;

d. a diagênese gerou níveis silicif içados (silcretes) resultantes da remobilização e precipitação da silica em condições superficiais. O cimento é composto por sih'ca amorfa e microcristalina, esta última na forma de franja envolvendo os grãos detríticos do arenito, com calcedônia fibrosa preenchendo os poros remanescentes. Ocorrem também lepisferas de cristobalita incorporadas ao cimento silicoso;

e. análises químicas de rocha total (ICP) mostraram que os silcretes Três Barras exibem teores inferiores de silica e superiores de alumínio, ferro, potássio e sódio, com relação aos silcretes australianos e sul-africanos descritos na literatura. Tal fato foi interpretado como resultante de processos diagenéticos ainda em evolução nos silcretes Três Barras;

f. os calcretes Três Barras foram formados a partir dá cimentação carbonática de arenitos eólicos da mesma unidade. Análises químicas de rocha total (ICP) mostraram, quantitativamente, que o processo de introdução do cálcio envolveu a retirada de sflica, alumínio, ferro e potássio do sistema. A petrograf ia óptica mostrou que o cimento calcífero é formado por calcita espática e os grãos de quartzo mostram-se localmente fragmentados pela expansão do cimento, assim como apresentam bordas intensamente corroídas;

g. análises químicas de rocha total (ICP) executadas nas rochas vulcanoclásticas associadas aos arenitos cimentados por carbonato de cálcio e os dados de campo sugerem que aquelas rochas comportaram-se como fornecedoras do material carbonático cimentante;

h. estruturas direcionais observadas nos arenitos eólicos Três Barras indicam predominância de direção de transporte do sul para o norte. Tal fato, aliado ao caráter policíclico dos grãos de quartzo, sugere uma proveniência a partir dos arenitos eólicos da Formação Botucatu (Mesozóico da Bacia do Paraná); i. os arenitos eólicos Três Barras podem, localmente, constituir platôs de topo plano, observados a norte da área estudada. Nesses locais, eles se situam diretamente sobre o embasamento, sendo recobertos por níveis de laterito ferruginoso de espessuras variáveis e exibindo intensa alteração intempérica, que mascara totalmente as texturas diagnosticas do ambiente eólico.

Agradecimentos $\mathrm{O}$ autor agradece aos geólogos Joel C. de Castro e Sylvia M. Couto (PETROBRAS/CENPES) pelo acompanhamento ao campo e utilização do MEV; aos geólogos Pedro de Cesero (PETROBRAS/CENPES) e Luiz F. De Ros (ICG/UFRS), pelo apoio no campo da petrografia microscópica. Agradecimentos também são devidos ao geólogo Mauro F. Yamamoto pelas análises químicas por ICP (Laboratório NOMOS de Análises Químicas, RJ). As análises por microssonda eletrônica foram realizadas sob a supervisão do geólogo Luiz R. A. Garcia (CVRD/BH), ao qual o autor também agradece. O professor João Henrique Grossi Sad (IGC/UFMG) gentilmente realizou a leitura do texto, fornecendo sugestões valiosas. Os recursos financeiros foram supridos pela PETROBRÁS por meio do Setor de Programas Externos (processo 30050 SEDES-SEPEX) e pelo Conselho Nacional de Desenvolvimento Gentífico e Tecnológico CNPq (processo 23072052154/87-54). O autor é grato também ao Departamento de Geologia da UFRJ pela infra-estrutura colocada à disposição durante os trabalhos da dissertação.

\section{REFERÊNCIAS BIBLIOGRÁFICAS}

ARBEY, F. 1980. Les formes de Ia silice et l'identification des évaporites dans lês formations silicifíées. Bull Cent. Rech. Expl Prof. Elf-Aquitaine, p. 309-365.

ARROJADO LISBOA, M.A.R. 1906, Ocorrência de seixos facetados no Planalto Central do Brasil. Anais Esc. Minas de Ouro Preto, 8:25-74.
BAKER, H.W. 1976. Environmental sensitivity of submicroscopy surface textures on quartz sand grains - A statistical evaluation. J. SecL Petrol., 46:871-880.

BARBOSA, O.; BRAUN, O.P.G.; DYER, R.C.; CUNHA, C.A.B.R. 1970. Geologia da Região do Triângulo Mineiro. Bol., 136:140 p. 
BASKIN, Y. 1956. A study of authigenic feldspars. J. GeoL, 64:132-155. BJORNBERG, A.J.S.; GANDOLFJ, N.; PARAGUASSU, A.B. 1964 Ocorrência de prismas hexagonais de arenito em São Carlos, SP (Formação Botucatu). Boi. Soe. Bros. Geol, 13(1/2):61-66.

BLATT, H. 1979. Diagenetic processes in sandstones. In: SCHOLLE, P.A. \& SCHLUGER, P.R. eds. Aspects of Diagenesis. Tulsa, Okla, Soc. Econ. Paleon. Miner, p. 141-157. (SEMP Spec. Publ. 26).

BRAUN, O.P.G. 1970. A Formação Areado e a Formação Serra Negra. Rev. Esc. Minas de Ouro Preto, 28:100-106.

BRUHN, C.H.L. 1986. Relações entre a diagênese dos arenitos e transformações nos folhelhos e carbonatos associados - um exemplo do Membro Gomo, Formação Candeias, Bacia do Recôncavo, Bahia. In: CONGR. BRÁS. GEOL., 34. Goiânia, 1986. Anais... Goiânia, SBG. v. 1, p. 80-93.

CARDOSO, R.N. 1968. Contribuição ao estudo do Grupo Areado: Estratigrafia e descrição dos filópodos fósseis. In: CONGR. BRÁS GEOL., 22. Belo Horizonte, 1968. Resumo das Comunicações... Belo Horizonte, SBG. p. 56-57.

CHOQUETTE, P.W. \& PRAY, L.C. 1970. Geologic nomenclature and classification of porosity in sedimentary carbonates. Am. Assoc. Pet. GeoL Bull, 54:207-250.

CRONE, A.J. 1975. Laboratory and field studies of mechanically infiltrated matrix clay in arid fluvial sediments. Denver. 162 p. (Ph D. Thesis, University of Colorado)

DE ROS, L.F. 1986. Petrologia e características de reservatório da Formação Sergi (Jurássico) no campo de Sesmaría, Bacia do Recôncavo, Brasil Ouro Preto. 107 p. (Dissertação de Mestrado, UFOP).

DE ROS, L.F. \& MORAES, M.A.S. 1984. Seqüência diagenética em arenitos uma discussão inicial. In: CONGR. BRAS. GEOL., 34. Goiânia, 1986. Anais... Goiânia, SBG. v. 1. p. 894-902.

FOLK, R.L. 1965. Some aspects of recrystalization in ancient limestones. In: PRAY, L.C. \& MURRAY, R.C. eds. Dolomitization and Limestone Diagenesis. Tulsa, Okla., Soc. Econ. Paleon. Miner, p. 14-48 (SEMP Spec. Publ. 13)

FOLK, R.L. 1973. Carbonate petrography in the Post-Sorbian age. In: GINSBURG, R.N. ed. Evolving Concepts in Sedimentology. Baltimore, John Hopkins Univ. Press, p. 118-158.

FREYBERG, B.V. 1965. Ergebnisse geologischer forschungen in Minas Gerais (Brasilien). In: CONOR. BRAS. GEOL., 19. Rio de Janeiro, 1965. Anais... Rio de Janeiro, SBG. p. 129-173.

GOUDffi, A. 1972. The chemistry of world calcrete deposit J. GeoL, 80:449-463.

GROSSI SAD, J.H.; CARDOSO, R.N.; COSTA M.T. 1971. Formações Cretácicas em Minas Gerais: uma revisão. Rev. Bras. Geoc., 1:1-13.

GUIMARÃES, D. 1951. Arqui-Brasil e sua evolução geológica. Rio de Janeiro, DNPM. p. 132-167. (Boi. 88).

HASUI, Y 1968. A Formação Uberaba. In : CONGR. BRÁS GEOL, 22 Belo Horizonte, 1968. Anais... Belo Horizonte, SBG. v. 1, p. 167-179.

KASTNER, M. \& SEVER, R. 1979. Low temperature feldspars in sedimentary rocks. Am. J. ScL, 279: 435-479.

KRINSLEY, D.H. \& DONAHUE, J. 1968. Environmental interpretation of sand grain surface textures by electron microscopy. GeoL Soc. America Bull, 79:743-748.

KRINSLEY, D.H.; FRIEND, P.F.; KLIMENTIDIS, R. 1976. Eolian transport textures on the surface of sand grain of Early Triassic age. GeoL Soc. America BulL, 87:130-132.

LADEIRA, E.A.; BRAUN, O.P.G.; CARDOSO, R.N., HASUI, Y. 1971. O Cretáceo em Minas Gerais. In: CONOR. BRAS. GEOL., 25. São Paulo, 1971. Anais... São Paulo, SBG. v. 1, p. 15-31.

LADEIRA, E. A. \& BRITO, O.E. A. 1968. Contribuição à geologia do Planalto da Mata da Corda. In: CONGR. BRAS. GEOL., 22. Belo Horizonte, 1968. Anais... Belo Horizonte, SBG. v. 1, p. 181-199.

MARGOLIS, S.V. \& KRINSLEY, D.H. 1971. Submicroscopic frosting on eolian and subaqueous quartz sand grains. GeoL Soc. Am. Bull., 82:3395-3406

McKEE, E.D : DOUGLAS, J.R.; RITTENHOUSE, S. 1971. Deformation of leeside laminae in eolian dunes. GeoL Soc. Am. Bull, 82:359-378.

McKEE, E.D. \& TEBBITS Jr., G.C. 1964. Primary structure of a seif Dune and associated deposits in Libya. J. Sed Petrol. 34:5-17.
MEYER. R. \& REIS, R.B.P. 1983. Paleosoils and alunite silcretes in continental Cenozoic of western Portugal. J. Sed Petrol, 55:76-85.

MORAD, S.; MARFJL, R.; DE LA PENA, J.A. 1989. Diagenetic K-feldspar pseudomorphis in the Triassic Buntsanstein sandstones of the Iberian Range Spain Sedimentology, 36:635-650.

MORAES, M.A.S. \& RAJA GABAGLIA, G.P. 1986. Arenitos eólicos intercalados em seqüências fluviais: critérios para o reconhecimento. In: CONGR. BRÁS. GEOL., 34. Goiânia, 1986. Anais... Goiânia, SBG. v. 1, p. 246-261.

MULTER, H.G \& HOFFMEISTER, J.E. 1968. Subaerial laminated crusts of the Florida Keys. Geol. Soc. Am. Bull 79:183-192.

OEHLER, J.H. 1976. Hydrothermal crystallization of silica gel. GeoL Soc. Am. BulL. 79:973-1008

PARAGUASSU, A.B. 1972. Experimental sUification of sandstone. GeoL Soc. Am. Bull, 83:2853-2858.

PETRI, S. 1983. Brazilian cretaceous paleoclimates: evidence from clay minerals, sedimentary structures and palynomarphs. Rev. Bras. Geoc. 13(4):215-222

PETTUOHN, F.J.; POTTER, P.E.; SIEVER, R. 1987. Sand and Sandstone 2 ed. New York, Springer-Verlag. $553 \mathrm{p}$

POLLARD, CO., Jr. \& WEAVER, C.E. 1973. Opaline sphere: loosely packed aggregates from silica nodule in diatomaceous Miocene fuller's earth. J. Sed Petrol, 43:1072-1076.

SELLEY, R.C. 1982. An introduction to Sedimentology. 2 ed. London, Acad Press Inc. $417 \mathrm{p}$.

SGARBI, G.N.C. 1989. Geologia da Formação Areado: Cretáceo Inferior a Médio da Bacia Sanfranciscana oeste do Estado de Minas Gerais. Rio de Janeiro. 324 p. (Dissertação de Mestrado, UFRJ).

SGARBI, P.B.A. 1991. Geologia, Petrologia e Geoquímica da Formação Mata da Corda. Rio de Janeiro. 214 p. (Dissertação de Mestrado, UFRJ)

SJEVER, R. 1957. The silica budget in the sedimentary cicle. Am. Mineral, 42:821-841.

SEVER, R. 1962 . Silica solubility, $0^{\circ}-200^{\circ} \mathrm{C}$, and the diagenesis of siliceous sediments. J. GeoL, 70:127-149.

SMALE, D. 1973. Silcretes and associated silica diagenesis in Southern Africa and Australia. J. Sed Petrol, 43:1077-1089.

STEIDTMANN, J.R. 1974. Evidence of eolian origin of cross-stratification in sandstones of the Casper Formation, Southernmost Laramie Basin, Wyoming. GeoL Soc. Am. Bull, 85:1835-1842.

STEPHENS, C.G. 1971. Latente and silcrete in Australia: A study of the genetic relationships of latente and silcrete and their companion materials, and their collective significance in the formation of the weathered mantle, soils; relief and drainage of the Australian continent. Geoderma, 5:5-42.

SUGUIO, K. \& BARCELOS, J.H. 1983. Paleoclimatic evidence from the Areado Formation, Cretaceous, of the São Francisco Basin, state of Minas Gerais. Rev. Bras. Geoc., 13(4):232-236.

TUCKER, M.E. 1985. Sedimentary Petrology - An Introduction. Oxford, Blackell Sci. Pub. 252 p.

WALKER, T.R. 1967a. Formation of red beds in modern and ancient deserts. GeoL Soc. America Bull, 78:353-368.

WALKER, T.R. 1967b. Color of recent sediments in tropical Mexico. A contribution to the origin of red beds. GeoL Soc. Am. Bull, 78:917-920.

WALKER, T.R. \& HONEA, R.M. 1968. Iron content of modem deposits in the Sonoram Desert: A contribution to the origin of red beds. Geol Soc. America Bull, 80:535-544.

WALKER, T.R.; WAUBH, B.; CRONE, A.J. 1978. Diagenesis in first cicle desert alluvium of Cenozoic age, southwestern United States and northwestern Mexico. GeoL Soc. Am. Bull, 89:19-32.

WILLIAMS, L.A.; PARKS, G.A.; CRERAR, D.A. 1985. - Silica diagenesis, I-Solubility controls. J. Sed Petrol, 55:301-311.

WILLIAMSON, WO. 1957. Silicified sedimentary rocks in Australia. Am. J. ScL, 255:23-42.

MANUSCRITO A680

Recebido em 12 de novembro de 1990 Revisão do autor em 4 de dezembro de 1991 Revisão aceita em 12 de dezembro de 1991 